\title{
THERMAL CONDITIONS IN
}

MONTEREY BAY DURING SEPTEMBER 1966

THROUGH SEPTEMBER 1967

AND JANUARY 1970

THROUGH JUNE 1971

RAYMOND CHARLES ANDERSON 
$T, T P R A R Y$

2. 'I POSTCRADUATE SCHOOL

lLVIV'LPLY, CLLIF. 93940 






\section{United States \\ Naval Postgraduate School

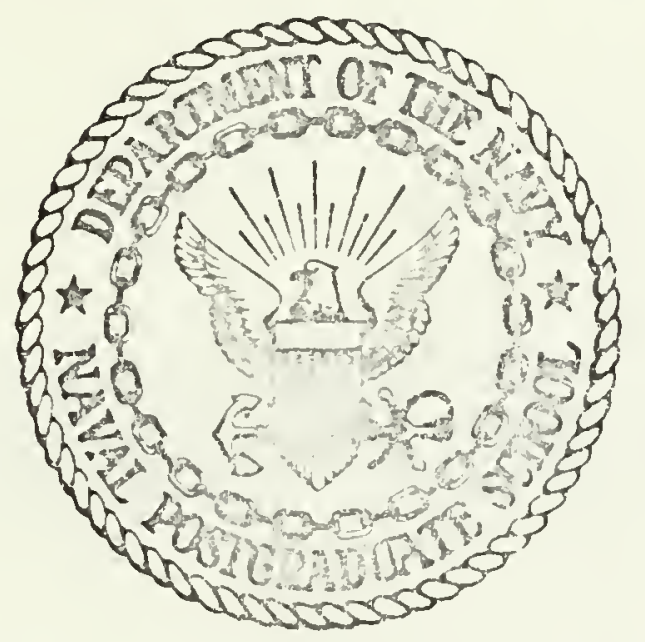

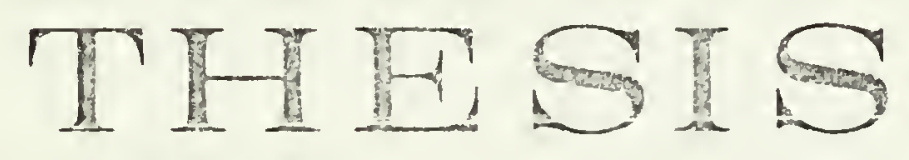

THERMAL CONDITIONS IN MONTEREY BAY

DURING SEPTEMBER 1966 THROUGI SEPTEMIBER 1967

AND JANUARY 1970 THROUGII JUNE 1971

by

Raymond Charles Anderson

Thesis Advisor: Dr. Dale F. Leipper

September 1971

Approved for public release; distribution wrlimited. 
$\ldots+1$, CALIT. Yu 20 
Thermal Conditions in Monterey Bay during September 1966 through September 1967 and January 1970 through June 1971 by

Raymond Charles Anderson

Lieutenant Commander, United States Navy B.S., Illinois Institute of Technology, 1963

Submitted in partial fulfillment of the requirements for the degree of

MAS'IER OF SCIENCE IN OCRANGGRAPII

from the

NAVAL POSTGRADUATE SCHOOL

September 1971 



\section{ABSTRACT}

Thermal conditions in Monterey Bay during September 1966 through September 1967 and January 1970 through June 1971 were described by comparing direct observations taken at nearly weekly intervals to the long-term (40 years) averages, or "norms," developed by Lammers (1971). Station locations were distributed throughout the bay with most located over the axis of Monterey Submarine Canyon or in the southern half of the bay. Temperature data from three transects taken out to a distance of some 80 miles in August 1970 were compared to observed thermal conditions in the bay during four quasi-synoptic (one to three day) periods in August.

It was found that the norms provide an excelient basis to which direct temperature observations during quasi-synoptic periods may be compared. Such comparisons of certain thermal indices (depth of the $9^{\circ} \mathrm{C}$ isotherm, temperature at 20 meters, and sea surface temperature) at key locations (southern shallows, deep canyon, and shallow canyon) are valuable parameters in identifying the three climatic seasons (upwelling, oceanic, and Davidson Current) as well as the existence of anomalous thermal conditions. Further study into the nature of these anomalies could lead to better understanding of the dynamics of water movements in Monterey Bay. 



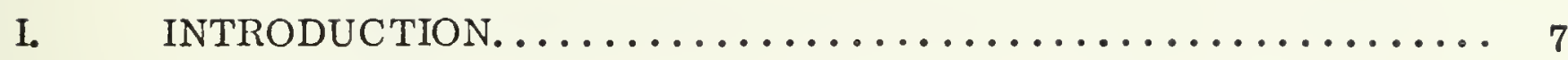

A. GENERAL............................ 7

B. DESCRIPTION OF MONTEREY BAY.............. 8

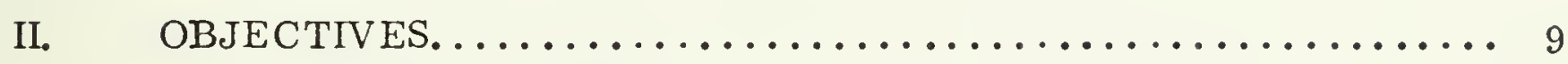

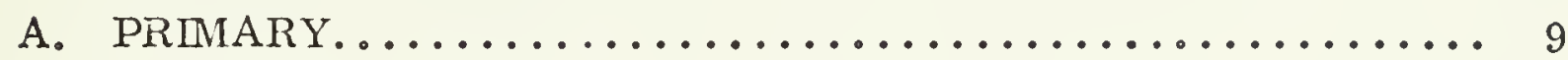

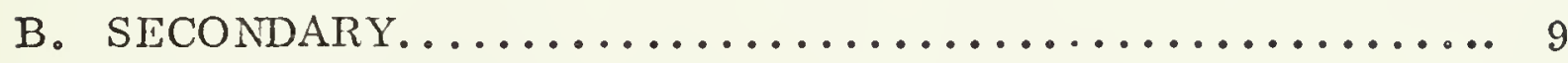

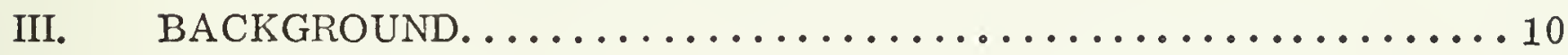

A. GEnERAL............................... 10

B. CALIFORNIA CURRENT....................... 10

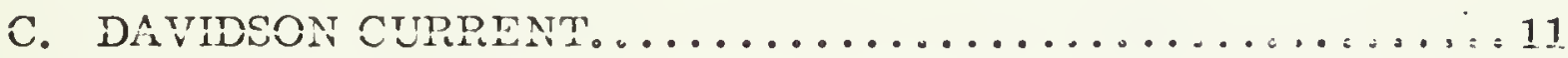

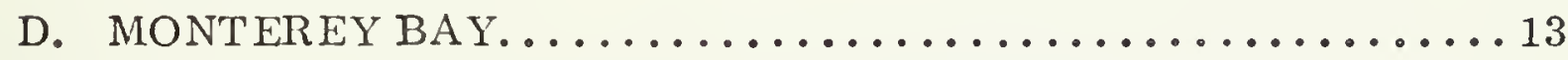

1. Bigelow and Leslie $(1930) \ldots \ldots \ldots \ldots \ldots \ldots \ldots \ldots$

2. Skogsherg (1936) and Skogsberg and Phelps (1946)...... 13

3. Bolin (1964)............................ 15

4. Bolin and Abbott (1963) and Abbott and Albee (1967).... 16

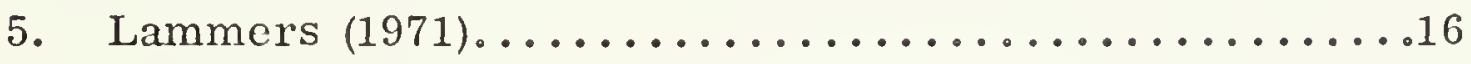

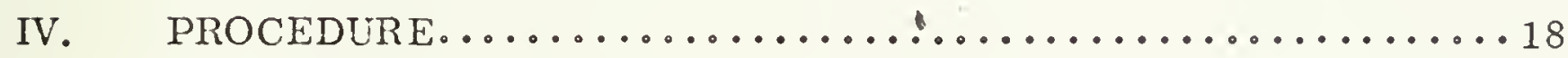

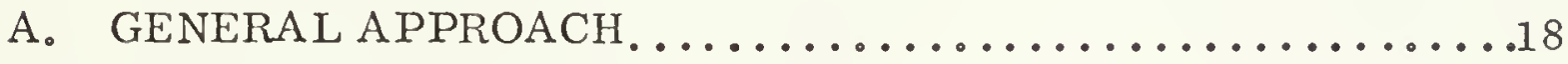

B. SELECTION OF STATIONS, ISOTHERMS, AND DEPTHS.... 18

C. DESCRIPTION OF FIGURES.........................

1. Time Series (Figures $3-17) \ldots \ldots \ldots \ldots \ldots \ldots \ldots \ldots$ 

2. Quasi-synoptic Horizontal Distributions of the Sea Surface Temperature and Selected Isothermal Surfaces (Figures 18-31).

3. West-to-East and South-to-North Correlation Diagrams

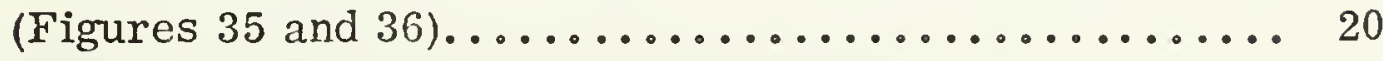

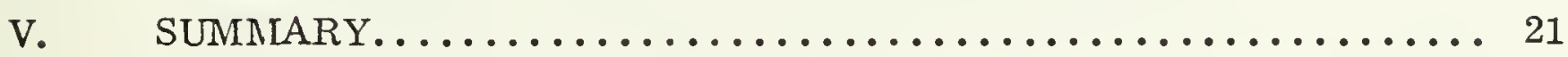

A. GENERAL FEATURES..................... 21

B. THERMAL CONDITIONS DURING CERTAIN QUASI- 23 SYNOPTIC PERIODS..................... 23

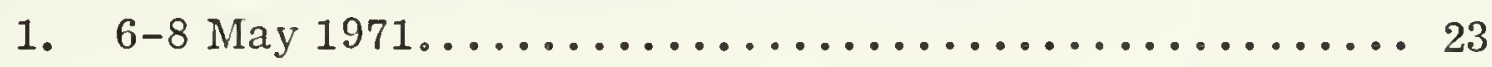

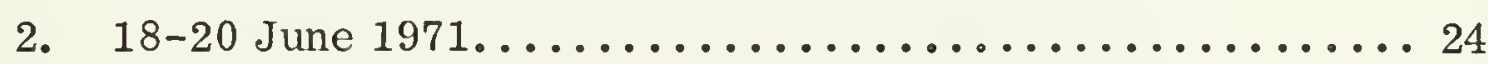

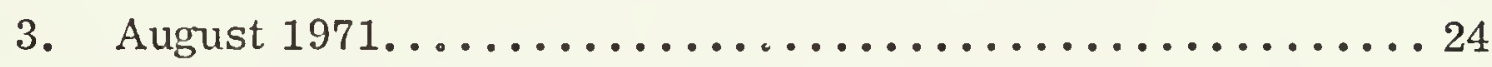

C. SOUTH-TO-NORTH AND WEST-TO-EAST GRADIENTS. ....2 26

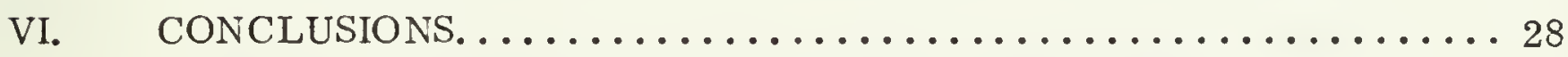

VII. RECOMMENDATIONS. ............................. 30

APPENDIX A: Data Sources and Collection Procedures........... 32

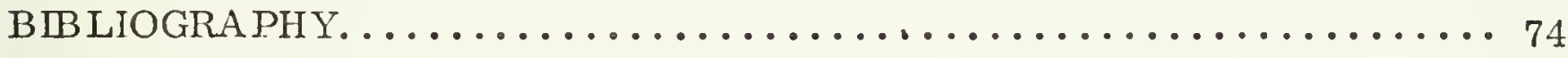

INITIAL DISTRIBUTION LIST, $\ldots \ldots \ldots \ldots \ldots \ldots \ldots \ldots \ldots \ldots \ldots$

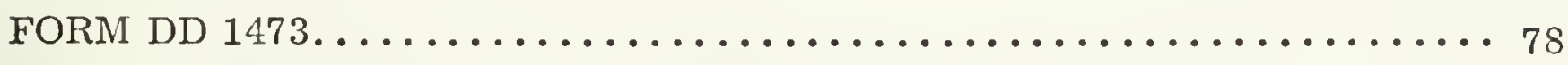





\section{LIST OF FIGURES}

1

California Ceniral Coast

2

Monterey Bay Showing Lammers' (1971) Blocks, NPS Stations 1-4 of 1966-67, Hopkins Stations 1-6, and NPS Stations 1-7 of 1970-71

3-8 Variation with Time of Thermal Indices at Key Locations during Period I

9-17 Variation with Time of Thermal Incices at Key Locations during Period II

18-20 Horizontal Distributions of Sea Surface Temperature and Selccted Isothermal Surfaces during 6-8 May 1971

21-24 Horizontal Distributions of Sca Surface Tempcrature and Selected Isothermal Surfaces during 18-20 Junc 1971

25-31 Horizontal Distributions of Sca Surface Temperature and Selected iscutierinal Surfaces during August 1270

32-34 Vertical Cross-Scctions from the California Coast in the vicinity of Monterey Bay to about 80 miles takcn during August 1970

35

South (southcrn shallows location) to North (deep canyon location) Correlations of Certain Thermal Indices of Periods I and II

West (deep canyon location) to East (shallow canyon location) Correlation of Certain Thermal Indices for Periods I and II 



\section{LIST OF TABLES}

I. Deviations From the Norm of Sea Surface Temperature at a Deep Canyon Location from 22 January 1970 to 7 April 1971

II. Deviations From the Norm of Sea Surface Temperature at a Shallow Canyon Location from 22 January 1970 to 7 April 1971 



\section{INTRODUCTION}

\section{A. GENERAL}

That the population of the world is increasing at an extraordinary rate is well known。 It is also realized that an increasing world population requires better understanding of the "world environment." This is of course necessary in order to determine the large-scale effects of increasing pollution and decreasing food supplies.

In the United States, population growth is very high along the East and West Coasts. In particular, the population of many communities located around Monterey Bay is becoming so large as to cause much concern over the problem of how to most effeciiveì dispose of an ever-increasing volumo of scwage. Since the traditional solution has been to "dump" this effluent into the nearest body of water, it is clearly desirable to determine what results this may have upon the local waters. This requires knowledge of prevailing currents and diffusion processes.

Another form of pollution is thermal pollution. When large volumes of water at relatively high temperatures are introduced into a local body of water, chemical reaction rates can change. Therefore, it is desirable to know the average or normal thermal conditions in order to detect changes as they occur.

Additionally, Monterey Bay is of interest because it once was a considerable food source (the California sardine). Although commercial fishing has w aned with the disappearance of the sardine, the bay still remains a potentially great food source. This potential exists because of the periodic upwelling of 

deep, nutrient-rich waters into the upper layers of the bay. Thus it is apparent that the bay meets both criteria for requiring further understanding of its oceanographic conditions; it is a potential food source and a depository for increasing amounts of "pollution."

In view of the above it is hoped that this study will lead to a better understanding of thermal conditions in Monterey Bay.

\section{B. DE SCRIPTION OF MONTEREY BAY}

Monterey Bay (Figure 2) is almost semi-elliptical in shape with wide communication to the open sea through a distance of almost twenty miles, as measured from Point Pinos in the south, to Point Santa Cruz in the north. Dominating the topogxaphy of the bay is one of the world's largest submarine canyons. The axis of Monterey Submarine Canyon tends westward, neariy bisecting the bay, from langitude $121-48 \mathrm{~W}$ to about $122 \mathrm{~W}$ where it turns abruptly southward for approximately five miles. From this point it tends westward again for a few miles before taking on a generally southwest track to about 122-10W which marks the westward limit of the area studied herein. Because of the presence of the canyon most of the waters of Monterey Bay and its seaward boundary are deeper than 100 fathoms. This, and the steep slope of the canyon's walls have a significant effect on the oceanographic conditions of the bay. 



\section{OBJECTIVES}

\section{A. PRIMARY OBJECTIVE}

The primary purpose of this study is to describe thermal conditions in Monterey Bay during the various periods of September 1966 through September 1967 (Period I) and January 1970 through June 1971 by comparing direct observations during these two periods to the long-term (40 years) averages developed by Lammers (1971). Lammers' work is discussed in Chapter III, paragraph D. 3. The data analyzed were collected by the Naval Postgraduate School, Monterey, California (NPS) and Hopkins Marine Station, Stanford University, Pacific Grove, California.

\section{B. SECONDARY OBJEC'TIVE}

Possible relationships of thermal conditions in Monterey Bay during Periods I and II to the California Current System are also described. 



\section{BACKGROUND}

\section{A. GENERAL}

To put the thermal conditions of Monterey Bay into the proper context it is first necessary to present a brief summary of pertinent literature. Therefore, applicable papers addressing the California Current, Davidson Current, and Monterey Bay itself are discussed below.

\section{B. CALIFORNIA CURRENT}

The California current is a southeastward flow along the western coast of North America. It is a part of the great clockwise circulation of the North Pacific Ocean, Reid, Roden, and Wylie (1958) noted that it flows between a cell of high atmospheric pressure to the west and a cell of low pressure over land to the east.

Since temperatures in the open ocean are lower toward the north, the California current gradually warms as it moves slowly south at speeds generally less than half a knot. This warming is both from solar radiation and from mixing with the warmer waters farther offshore. At a latitude of about 25 degrees north the current begins to turn westward and its waters become part of the west-flowing North Equatorial Current.

Wooster and Reid (1960), in a qualitative description of eastern boundary currents based on the sub-surface distribution of density or temperature, indicated that the California Current is generally restricted to a relatively shallow layer in most places above a depth of 500 meters. They further ascribed a 

maximum width to the eurrent of about 500 miles as measured from the eoast to its western boundary. Direet measurements using drogues set at 10 meters were eondueted by Jennings and Sehwartzlose (1960). They identified a 75 mile wide portion of the California Current flowing southward eentered about a point some 30 miles off Pt. Sur during Mareh 1958. The average speed observed was approximately 0.5 knots.

\section{DAVIDSON CURRENT}

Munk (1950) theorized that the California eurrent depends upon the vortieity of the meridional winds with wind stress vortieity balancing planetary vorticity. Beeause of the variation of the wind speed with distanee from shore, the curl of the wind stress ehanges sign. In his development Munk showed that this condition yielded a change in the sign of the direction cf trarsport indicating the prescnee of a eountereurrent between the California Current and the eoast. This eountereurrent has been observed and is known as the Davidson Current. Surprisingly little has been written about this eoastal eountereurrent. The more signifieant work is summarized below。

Wooster and Reid (1960) claimed the countercurrent is present throughout the year flowing to the northwest along the coast from Baja, California to at least 40 degrees north. This was based on the examination of cross-stream density profiles whieh showed a nearshore weakening of the vertical density gradient with a shoreward deepening of the isopycnals below 100-200 meters. A similar deepening of isopleths of other properties (e.g. temperature) oecurred. The poleward geostrophic flow associated with this distribution of mass is apparent on dynamie eharts of the 200 deeibar surfaee. 

A somewhat different description was given by Sverdrup, Johnson, and Fleming (1942, p. 727). They found that the coastal countercurrent exists at all depths exccpt during periocis of upwelling at which time it disappears from the surface layer (which is usually considered to exist to a depth of 200 meters). It was suggested (p. 677) that the countercurrent may be related to lateral mixing or to heating when the current (California Current) flows southward. Reid and Schwartzlose (1962) measured the Davidson Current directly using parachute drogues set at 10 meters. A surface flow existing bcfore the commencement of southerly winds was found. This current continued until well after the winds had become northerly again indicating a flow independent of local wind direction. This does not agree with the theoretical analysis of Munk (1950) who attributed the countercurrent to the curl of the local wind stress as mentioncd above. Dircct measurements of the Davidson Current have been made on other occasions. Rcid (1962) charted parachutc drogues set at 250 meters during November 1961. Their travel indicated a northward flow some 40 miles wide extending seaward from the 1000 fathom isobath off Montcrey Bay at latitude 36 degrces 45 minutes north. The maximum speed mcasured was 0.44 knots. Schwartzlose (1963) summarized the results of drift bottle returns for the pcriod of January 1955 through June 1960. He found that the predominant feature indicated by these returns was the countercurrent during the fall, winter, and early spring months from central California north to British Columbia. By Octobcr it appeared off Point Conception disappearing in April. The flow was found to be at lcast fifty miles wide with speeds of at least $0.5-0.9$ knots for distances of scveral hundred miles. 

D. MONTEREY BAY

There have been relatively few studies of the physical oceanography of the bay. The bibliography of Monterey Bay compiled by Moss Landing Marine Laboratories (Baron (1971)) contains some 227 pages of references of which only 24 concern physical oceanography. The papers discussed below represent the most significant efforts at describing oceanographic conditions in the bay and were especially useful as background material for this thesis.

\section{Bigelow and Lcslie (1930)}

Bigelow and Leslie conducted the first hydrobiological survey of Monterey Bay (Skogsberg (1936)). The variation with depth of temperature (as well as that of other physical paramcters such as salinity and silicate at most stations) was ohtaincd at 29 stations in the bay over the pcriod of 30 June to 24 July 1928. The data were assumed to be synoptic and the horizontal distributions of sea surface tempcrature, tempcrature at dcpths of 10 mctcrs and 100 meters, and the depths of the $9{ }^{\circ} \mathrm{C}$ and $10^{\circ} \mathrm{C}$ isotherms werc plotted. Vertical scctions across the bay and along the canyon's axis were also contourcd. From these plots it was concluded that upwelling tended to flow up the slopes of the sides of the canyon toward the canyon's head from a depth of at least 250 meters. Regarding horizontal circulation it was stated that an anticyclonic system existcd at the mouth of the bay. This was attributed to the shoreward spread of the colder upwclled waters leaving a quiescent area of relatively warm light waters along the axis of the canyon. Assuming that such watcrs are to the right of the flow a clockwise circulation will be devcloped.

2. Skogsberg (1936) and Skogsberg and Phclps (1946) 

An intensive study of thermal conditions was conducted during the years 1929 - 1937 by Hopkins Marine Station. These two reports constitute important background material for many of the subsequent studies of Monterey Bay. A considerable number of time series graphs based on monthly averages at stations in the southern part of the bay were considered representative of conditions throughout the entire bay. These graphs plus diagrams of vertical sections of temperature led to the following conclusions (among others): First, conditions in the southern end of the bay were dependent upon forces outside the bay. Second, according to Skogsberg (1936) an open mcander in the bay's circulation represcnted a more or lcss deep bend in a side branch of the general coastal flow while a closed eddy with clockwise flow indicated a northerly coastal current. Finally, counterclockwisc closed eddies were considcred to result from a southerly coastal flow.

An important contribution to better understanding the oceanography of Monterey Bay was the description of threc distinct phases of water movements underlying different segments of the annual rhythm. These werc defined as the cold water (upwelling), warm water (occanic), and low thermal gradient from the surface to 100 meters (Davidson Current) phascs.

It was found that upwelling, by far the most dominant phase, was intermittent and rhythmic beginning as early as December and generally ending by Septembcr. The upwelling occurred at some unknown distance outside the bay with the cold waters being advected toward the bay.

The oceanic pcriod follows upwclling and is charactcrized by the presence in the bay of watcr of truly oceanic origin. This water is derived in 

large part from the California Current which is warmer than the coastal waters. The appearance of these waters in Monterey Bay often reflects the change in the dominant wind direction and decrease in wind speed typical of the months of September to November. During this period sea surface temperatures in the bay are at their maximum annual values.

Between the oceanic and upwelling phases the waters of the bay typically have a low vertical thermal gradient in the upper 100 meters. This was attributed to the advection of subsurface warm waters from lower latitudes by the Davidson Current. It was speculated by Skogsberg that the Davidson Current is a wind current caused by southerly winds which prevail during the winter months.

\section{Bolin (1964)}

Bolin reported on an attempt to correlate variations in the abundance of certain marine organisms with fluctuations in hydrographic variables. A station located at 36 degrees 42 minutes north, 122 degrees 2 minutes west directly over the axis of the canyon was occupied on an almost weekly basis over the years 1951 - 1955. The three-phase annual cycle described by Skogsberg (1936) was corroborated by the variation in the depths of isotherms averaged by month. Characteristics of the three climatic seasons were refined somewhat。

Upwelling was typified by surface temperatures of $10-11^{\circ} \mathrm{C}$. Surface temperatures of $13^{\circ} \mathrm{C}$ or more characterized the oceanic period. Additionally, a strong thermocline at a depth of only a few meters was prevalent during most of the oceanic phase. A weakened thermocline present at depths of 50-100 

meters marked the Davidson Current period. The initiation of upwelling in late winter, marked by an abrupt decrease in the temperatures of the upper layer, signals the end of the Davidson Current phase.

\section{Bolin and Abbott (1963) and Abbott and Albee (1967)}

Thirteen years of data obtained by Hopkins Marine Station were discussed in these two reports. The first covered $1954-1960$ and the second summarized findings for 1961 - 1966. Approximately weekly samplings of one day duration were conducted in the bay at six hydrographic stations. Temperatures were averaged by month considering the bay as a whole. Time series graphs of both the average sea surface temperatures and the average temperature profile of the upper 50 meters were used to establish the fundamental features of the annual cycle of temperature. The analysis of this data substantially corroborated the conclusions of Skogsberg (1936) and Bigeiow and Leslie (1930). Some other features of the three climatic seasons were described as well as variations from year to year.

\section{Lammers (1971)}

The most recent work utiljzed in this study was that of Lammers. By compiling readily available temperature data collected over forty years Lammers was able to determine what are referred to as the monthly "norms" of both 1 horizontal and vertical temperature distributions in Monterey Bay.

The bay was divided into nineteen "blocks." The temperature data for a particular block were "lumped" together and assumed to apply to the block's geographic center. Sea surface temperature distributions over the bay and isothermal surfaces were contoured by month. Also, the annual cycle of 

the vertical temperature distribution was shown for several blocks.

Using these figures as well as average vertical sections it was concluded that there was indication of long-time progressive warming in the upper 100 meters with a resultant decrease in the intensity of upwelling. Additionally, spatial variations in the rates of upwelling and downwelling caused a "warm spot" to exist along the canyon's axis. The presence of waters over the canyon which are warmer than those in the northern and southern portions of the bay would tend to cause a clockwise circulation when conditions approximating geostrophic flow exist. 



\section{PROCEDURE}

\section{A. GENERAL APPROACH}

Three graphical methods of data analysis were used to present the deviations of thermal conditions in the bay during Periods I and II from the "norms." The first (Figures 3-17) involved depicting for selected stations the variation with time (time series) of: 1.) SST and 2.) depth of $9^{\circ} \mathrm{C}$ and $10^{\circ} \mathrm{C}$ isothermal surfaces.

Secondly, the horizontal distributions of: 1.) SST and 2.) selected isothermal surfaces were plotted (Figures 18-31) for the quasi-synoptic periods (one to three days) when the most data were available. It was assumed that

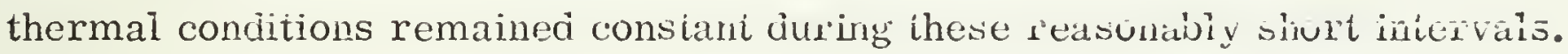
These figures are only a small portion of the more than 200 drawings prepared covering both Periods I and II. The additional drawings are included as an appendix to the master copy of this thesis which has been retained by the Oceanography Department of NPS.

The third approach employed was to plot the correlation of: 1.) SS'T, 2.) depths of the $9^{\circ} \mathrm{C}$ isotherm, and 3.) the temperatures at 20 meters for selected station pairs (Figures 35 and 36). This method shows in a rather concise form the deviations of the West to East and South to North temperature gradients over the two and half years analyzed.

\section{B. SELECTION OF STATIONS, ISOTHERMS, AND DEPTHS}

The parameters chosen for the various figures were based upon three 

considerations. Availability of sufficient data cluring Periods I and II was the first limiting factor. Next in importance was the location of the various stations with respect to Lammers" "blocks." Finally, it was necessary to determine at which stations and pairs of stations thermal conditions were best representative of the entire bay. In view of the above, three areas were chosen. Using the terminology of Lammers (1971), they were: 1.) a deep canyon station(s) 2.) a shallow canyon station(s) and 3.) a southern shallows station. The 50 fathom curve arbitrarily delineates as the boundary between the "shallows" and the "canyon."

\section{DESCRIPTION OF FIGURES}

\section{Time Series (Figures $3-17$ )}

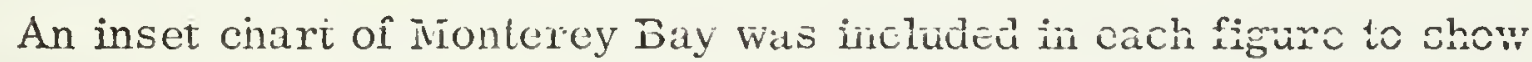
the general station locations and the applicable block. The normal variation with time of the parameter plotted was shown as a series of heavy, straight lines connecting the monthly averages for the particular block. Each normal monthly value of the parameter was assumed to occur in the middle of the month.

Light, straight lines were used to connect the data points (circles) for the particular time period under study at the particular NPS station. Where data were available from a Hopkins station in close proximity to the NPS station, the points were also plotted (as crosses). The presence of the Hopkins data points indicate some measure of the degree of temporal and spatial correlation between the two stations. 

2. Quasi-Synoptic Horizontal Distributions of the Sea Surface Temper:

ature and Selected Isothermal Surfaces (Figure 18-31)

Observed horizontal distributions of SST and selected isothermal surfaces were plotted together with their respective norms for the particular month of the quasi-synoptic period. The observed values were contoured as heavy, relatively smooth curves while the norms were taken directly from Lammers (1971) and plotted as light curves for comparison.

3. West to East and South to North Correlation Diagrams (Figures 35

and 36)

Temperature data from the station-pairs indicated in the figures were compared to the normal values for the respective blocks. Observed data points were plotted as " + 'S" when they were obtained cluring the upwelling season (mid-February to late July), "O' $\mathrm{S}$ " if obtained during the oceanic period (early August to mid-November) and " $\mathrm{S}$ " if obtained during the Davidson Current period (mid-November to mid-February). The norms were plotted as O'S" from Lammers' (1971) curves. 



\section{SUMMARY}

\section{A. GENERAL FEATURES}

Periods I and II were well-suited for this study although they were chosen by necessity, due to availability of data, rather than choice. From Figures 3-8 it is seen that the deviations of both SST and the depths of the $9^{\circ} \mathrm{C}$ and $10^{\circ} \mathrm{C}$ isotherms from their respective norms were generally within a well defined range throughout Period I. In particular, thermal conditions during the upwelling season (mid-March to late July) were very nearly normal at both the decp canyon and shallow canyon locations.

It seemed that the Davidson Current phase (mid-November to mid-Febru-

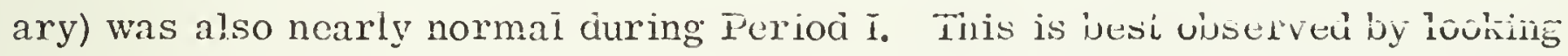
at the depth of the $9^{\circ} \mathrm{C}$ isotherm at the deep canyon station (Figure 4). The correlation between observed clata and the norms was not as good at the shallow canyon station: (Figures 7 and 8); but the general trend of the observed data points is in fair agreement with the norm. In December 1966 deviations of observed temperatures from their norms were much greater at the shallow canyon location than at the dequ canyon location. This suggests that either the same process of different intensities, or entirely different processes, affecting thermal conditions at the two locations, occurred during this month.

In contrast to the essentially normal thermal conditions of Period I, Figures 9-17 indicate that deviations of greater magnitude and variability occurred in Period II. Dominating thermal conditions in both 1970 and 1971 were the very intense periods of upwelling. During both years, from 

mid-February to late June, the $9^{\circ} \mathrm{C}$ and $10^{\circ} \mathrm{C}$ isotherms were present at much shallower depths than normal at the deep and shallow canyon locations (Figures 10-15). In 1970, upwelling was more intense at the deep canyon station (compare Figure 12 to Figure 13) while in 1971 thermal conditions at both canyon locations were similar (compare Figure 11 to Figure 14).

It is of interest to note that surface temperatures from January to March 1970 at the deep canyon location (Figure 9), shallow canyon location (Table II), and southern shallows station (Figure 16) were consistently $1.0-2.0^{\circ} \mathrm{C}$ higher than normal. Also, during these months the $9^{\circ} \mathrm{C}$ and $10^{\circ} \mathrm{C}$ isotherms were shallower than normal (Figures 11,12,13, and 15). Consequently, the characteristic feature of the Davidson Current Period, a low thermal gradient in the upper 100 meters, was preserved.

The upwelling period of 1970 lasted somewhat longer than normal (Figures $10,12,13$, and 15). This is reflected in the lower surface temperatures observed during the oceanic period of 1970 (August to mid-November) as shown in Figures 9, 16, and 17. By December 1970 sea surface temperatures had become normal. This suggests that by December the Davidson Current had appeared in the bay. Its presence would tend to warm the upper layers (depths less than 100 meters) through mixing as its warmer waters, probably entering the bay at depths greater than 100 meters, encountered the colder waters of the bay. Such an unstable condition might lead to convective mixing as the heat from those warmer waters diffused upward.

As mentioned previously (Chapter IV paragraph C. 1), some measure of the degree of temporal and spatial correlation between two stations in ciose 

proximity can be gained from several of the time series graphs. In Figures $3,5,9-12,16$, and 17 data from both NPS and Hopkins stations are shown. In most cases these data are in good agrecment when observations were made within about five days. Certain periods at particular locations were in general agreement over much longer time intervals. The best examples were at the deep canyon location during upwelling in 1967 and 1970 when the depth of the $10^{\circ} \mathrm{C}$ isotherm remained at a very nearly constant depth of 20 meters over periods of about six weeks (Figures 5 and 12).

In general then, time series graphs comparing observed temperatures with the norms can be very revealing with respect to the thermal conditions in the bay. Descriptions of horizontal distributions of sea surface temperature and isothermal surfaces can thus be best given in terms of these overall thermal conditions as well as observed characteristics of the California Current System.

\section{B. THERMAL CONDITIONS DURING CERTAIN QUASI-SYNOPTIC PERIODS}

\section{1. $6-8$ May 1971}

From the previous discussion of general features of thermal conditions in the bay it will be recalled that upwelling was more intense than normal during this time interval. Therefore, it is not surprising that the distribution of sea surface temperature shows that the surface waters of virtually the entire bay were about $1.0^{\circ} \mathrm{C}$ colder than normal (See Figure 18). Because the observed pattern is quite similar to normal it is suggested that the processes involved (heat budget, advection, and mixing) have been normal also over a considerable period.

This contention is supported somewhat by the distribution of the $10^{\circ} \mathrm{C}$ 

isothermal surface shown in Figure 20. The observed range of depths of the $10^{\circ} \mathrm{C}$ isotherm is from $10-20$ meters whereas normally it would be $20-30$ meters. The shallower observed depths may be attributed to the generally more intense upwelling which occurred in 1971.

Thermal conditions in the upper 50 meters of the bay are suggested by the pattern of the observed $9^{\circ} \mathrm{C}$ isothermal surface (Figure 19). From this pattern it is apparent that coldest watcrs were over the canyon axis at the mouth of the bay. The watcrs over the axis of the canyon to the cast were coldcr than those to the north and south. It is considered that this condition is transicnt and represents a "pulse" of upwelling advected toward the bay from offshorc.

\section{2. $\quad 18-20$ June 1971}

Although upwelling was more intense over this time interval, the trend of the depth of the $9^{\circ} \mathrm{C}$ isotherm in mid-Junc was downward, toward the norm (Figurcs 11 and 14), at the deep and shallow canyon locations. Sea surface temperaturc, as obscrved at the southern shallows location, (Figurc 17) appeared to be increasing, in this casc also approaching the norm.

The observed surfacc tempcrature pattcrn is similar to normal and gives no indication of unusual or anomalous sub-surface conditions. However, from Figures 21-24 it can be secn that the waters over the canyon had warmed since May whilc those of the northern and southern shallows had become colder. The implication is that the upwelled watcrs of May spilled up the sides of the canyon and left a "warm spot" over the axis。

\section{August 1970}

Thermal conditions in Monterey Bay may be discussed in conjunction 

with those of the offshore regime during this period because direct observations were made in both areas in August.

The time series graphs previously discussed (Chapter V, paragraph A) show that upwelling had eeased in the bay and the oceanic period had begun. Sea surface temperatures were high and the $9^{\circ} \mathrm{C}$ and $10^{\circ} \mathrm{C}$ isotherms had migrated downward. This is substantiated by Figures 25-31 which show a progressive warming of the upper 200 meters of the waters over the canyon at the mouth of the bay while sea surface temperatures remained nearly constant. This was undoubtedly caused by advection of warm oceanic waters into the bay by a side branch of the California Current.

Thermal conditions in the offshore regime are shown in Figures $32-34$ for the transects indicated in Figure 1. The upward slope of the shallow isotherms is characteristic of the California Current while the dipping of the deeper isotherms towards shore suggests a deep poleward countercurrent. This is exactly the situation described by Wooster and Reid (1960) as discussed in Chapter III, paragraph B.

The complex pattern of the upper 50 meters within 30 miles of the coast shown in Figure 33 is probably due to the interruption of the nearly straight shoreline by Monterey Bay (Figure 1). The upward slope of the shallow isotherms within 5 miles of the coast as shown in Figure 34 has been said, according to Hart and Currie (1960) as cited by Wooster and Reid (1960), to be a relic of previous upwelling. Therefore, it seems that offshore conditions are such as to have contributed significantly to the observed conditions in the bay. 



\section{SOUTH-TO-NORTH AND WEST-TO-EAST GRADIENTS}

In order to illustrate the normal changes of thermal conditions in Monterey in a concise form, graphical analyses of West-to-East and South-toNorth gradients were constructed. Figures 35 and 36 show observed gradients for the two and a half years studied in comparison to the norms. Arrows are included in the figures to indicate the changes in the normal gradients from month to month.

Two sets of location pairs were used in Figures 35 and 36: 1.) a South (Block 1 in the souther shallows)-North (Block 3 in the deep canyon) pair in Figure 35 and 2.) a West (Block 3)-East (Block 19 in the shallow canyon) pair in Figure 36. The charactcristics of the three climatic seasons suggested by these graphs are: 1.) upwelling begins at the deep canyon station before appearing at shallow canyon station (Figure 36A), 2.) the southern shallows location is cooling faster at 20 meters than the deep canyon location in the time interval from March to May (Figurc 35A), 3.) during this same period sea surfacc temperatures are increasing at southern shallows location while they are decreasing at deep canyon location (Figure 35B), 4.) the occanic and Davidson Current periods are virtually indistinguishable over the canyon at 180-200 meters (Figure 36A), and 5.) the oceanic period is best identified in Figure เ $36 \mathrm{~B}$ by high surface temperatures at both the deep canyon and southern shallows location.

By plotting direct observations of the thermal indices measured during quasi-synoptic periods anomalous thcrmal conditions and trends can be $r^{\circ}$ eadily identified. Examination of observed correlations during Periods I and II shows 

considerable "scatter." However, in general the data points reflect seasonal thermal conditions when compared to the nor ms. The more intense than normal upwelling seasons of 1970 and 1971 appear as points close to the origin of Figure $36 \mathrm{~A}$. Also, Figure $36 \mathrm{~A}$ shows the warming that occurred at the shallow canyon location but not at the deep canyon location during the upwelling season(s). 



\section{CONCLUSIONS}

1. Comparison of observed temperature parameters at key locations in Monterey Bay to their respective norms indicates the climatic season as well as the intensity of the season on a given day. The key locations are the deep canyon, shallow canyon, and southern shallows areas. The parameters involved are sea surface temperature, temperature at a depth of 20 meters, and the depths of the $9^{\circ} \mathrm{C}$ and $10^{\circ} \mathrm{C}$ isotherms.

2. The upwelling season is predominant among the three phases of the annual cycle of water movements in Monterey Bay. During Period I, upwelling was normal in intensity and the Davidson Current and oceanic periods were also normai. In 1970 and 1971 upwelling was more intcnse than normal while the other two seasonal phases were inconsistent and variable.

3. The more intense than normal upwelling observed in 1970 was preceded by an unusually warm Davidson Current Period and followed by a colder than normal oceanic period。

4. Observations of thermal conditions in Monterey Bay made within time intervals of about five days were reasonably consistent while those taken farther apart in time showed considerable variation.

5. During the upwelling seasons of Periods I and II subsurface waters over the canyon were generally warmer than those in the shallows areas.

6. Thermal conditions in Monterey Bay during August 1970 were significantly influenced by the presence of waters from the California Current. A side branch of the California Current resulted in a clockwise circulation under 

assumed geostrophic conditions.

7. During August 1970 the Davidson Current was found to be present in the offshore waters within 50 miles of the coast as a poleward flow below 150 meters. This conclusion is based upon three temperature cross-sections from the coast to 80 miles seaward. However, direct observations in Monterey Bay during four quasi-synoptic periods in the month indicated that essentially normal oceanic phase thermal conditions existed which were attributed to California Current waters (see paragraph 6 above) entering the bay above 150 meters. 8. Thermal conditions and water circulation in Monterey Bay can generally be ascribed to either the California Current, the Davidson Current, or steady local winds from the northwest causing upwelling. However, the many anomalous thermal conditions observed in Periods I and II indicate that local conditions (wind, solar radiation, tidal currents and internal waves), the irregular topography of Monterey Submarine Canyon, and interactions between the above three primary driving forces occur throughout the year. 



\section{RECOMMENDATIONS}

1. It has been shown that the norms developed by Lammers (1971) can be used as a basis for studying thermal conditions in Monterey Bay. However, attempts at finding patterns in the temperature distributions that were extant long enough to assume geostrophic conditions were often fruitless because of the time intervals between samplings of temperature at the various locations. Therefore, it is recommended that cruises of several days duration be made in the bay during the critical periods when thermal conditions in the bay are changing rapidly, i. e., during the periods of transition that separate the three climatic seasons. These periods would be identifiable by analyzing data obtained during the weekiy Day Ciuise Program of Nus presently in effect. The procedure employed in this thesis is invaluable in ascertaining these transition periods since use of the temperature parameters observed at key locations compared to their respective norms are excellent indices.

2. To better relate thermal conditions and water circulation in the bay to the three primary driving forces of upwelling, California Current, and Davidson Current, transects from the coast to distances of about 100 miles should be undertaken at regular intervals. Bettween each transect, or concurrently if possible, samplings of temperature in the bay at the key locations should be made. Naturally, simultaneous direct measurements of currents in the bay using current meters or drogues would be of significant value.

Coordination between the efforts of Moss Landing Marine Laboratories (Moss Landing), Hopkins, and NPS would be of mutual benefit in this regard. 

This coordination could be in the form of making the cruise schedules of each institution available to each other. The data obtained could be pooled in order to increase coverage. The computer capability of NPS could be utilized in the establishment of a data bank for the area of interest shown in Figure 1.

3. The cruise plan presently used by NPS should be modified as shown in Figure 37 to include broader coverage of the bay thereby providing data for updating Lammers norms in the weaker blocks. This cruise plan would maintain the three key locations of the southern shallows, deep canyon, and shallow canyon as well as including stations which would provide information on the offshore conditions. Data from the stations occupied in this cruise plan combined with that from Hopkins, Moss Landing, and a future floating research platform (to be emplaced in Monterey Bay to enable NPS to monitor various oceanographic parameters) should add significantly to the knowiedge of oceanographic conditions (temperature, salinity, currents, etc.) in Monterey Bay.

4. To better describe thermal conditions in Monterey Bay in terms of the offshore regime it is necessary to determine how other processes occurring concurrently are efiecting the variation of temperature with depth. Therefore, it is recommended that an integrated program involving the determination of the heat budget, diffusion of heat, internal waves, localized wind profiles, and tidal currents in the bay be undertaken. 



\section{APPENDIX A: DATA SOURCES AND COLLECTION PROCEDURES}

Data used in this thesis have been obtained from both NPS and Hopkins Marine Station for the two periods studied.

\section{A. SEPTEMBER 1966 to SEPTEMBER 1967}

\section{NPS}

From 27 September 1966 to 18 September 1967 NPS conducted fiftytwo one-day samplings of temperature and salinity in the bay on a nearly weekly basis. Four stations were occupied along the axis of Monterey Canyon. The stations locations are indicated on Figure 2. The data report, designated NPS $1970-1 / D$ is a part of the report file of the Oceanography Department of NPS.

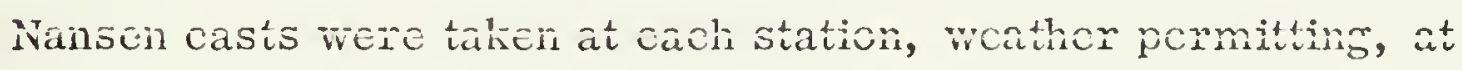
approximately standard depths from the surface to within 50 meters of the bottom. Temperature was measured using reversing thermometers. Linear interpolation was used between standard depths in order to construct the various graphs and plots of selected isotherms and isothermal surfaces.

Navigation was generally based on LORAC positioning. If, because of equipment malfunction, the LORAC system was rendered inoperative, either visual or radar fixes were used. In any case position accuracy is within one-half mile. This is considered adequate for this study.

\section{Hopkins}

Temperature data for this period were also extracted from Hopkins (1966 and 1967). Thirty-three samplings of temperature and salinity were made. Six stations were occupied during each sampling (Figure 2 shows station locations). 

Surface temperatures were obtained using a reversing thermometer.

A mechanical bathythermograph (MBT) was lowered to fifty meters at stations $2,3,4$, and 6 , to thirty meters at station 1 and to twenty meters at station 5 . Temperatures at ten meter intervals were listed in the reports. Again, linear interpolation was used where necessary to determine the depth of a particular isotherm. Navigational accuracy is assumed to be comparable to that of NPS.

B. JANUARY 1970 to JUNE 1971

\section{NPS}

Between 22 January 1970 and 2 June 1971 forty-one samplings of thermal conditions were made by NPS as part of a continuing study of temperature conditions in Monterey Bay. Seven stations (as indicated on Figure 2) werc cccupicd on a mowe or less weclly basis.

Surface temperature was measured using a bucket thermometer. An MBT was lowered at the shallow stations (1-3) while a Sippican expendable bathythermograph (XB T) was dropped at stations 4-7. Depths of the various isotherms were tabulated as well as bottom depth, BT depth, bottom temperature, etc.

The data from 1970 is from NPS 1971-1/D while that from 1971 will be filed as NPS 1972-1/D.

\section{Hopkins}

Data for 1970 were taken from Hopkins (1970) while that for January 1971 to June 1971 were made available to the author in an unpublished form. During the entire period some fifty-eight cruises were made generally according to the cruise plan shown in Figure 2. A slightly different procedure from that 

of 1966-67 was used however in obtaining the data.

Only fourteen cruises in 1970 involved the use of an MBT. In many cases only station 3 was occupied during a cruise. Also, a hydrocast was made at station 3 to depths usually between 200 and 500 meters.

\section{AUGUST 1970}

During the period of 10-20 August 1970 NPS conducted an oceanographic cruise on the USNS DE STEIGUER. Three ocean transects (Figure 1) and two bay transects (Figures 19-24 show the locations of hydrocast, MBT, and XBT stations) were made. This data is filed as NPS 1970-2/T.

\section{6-8 MAY 1971 and 18-20 JUNE 1971}

XBT's only were used to obtain temperature data during these two cruises. Station locations are as shown in Figures 25-28 for the former period and in Figures 29-33 for the latter. The 63-foot hydrographic research vessel was used in May. The data for June was gathered during a portion of the cruise of USNS BARTLETT. These data are included in NPS 1972-1/D.

\section{E. ACCURACY OF DATA}

No distinction has been made between reversing thermometer, MBT, or XBT data. Temperatures are assumed to be áccurate to within $0.3^{\circ} \mathrm{C}$ and depth within 1.0 meter based upon the known limitations of the various sources. Since thermal conditions are quite variable and the range of values observed is considerably greater than the possible errors, this accuracy is considered adequate for this study. 

Figure 1. Central California

\section{Coast}

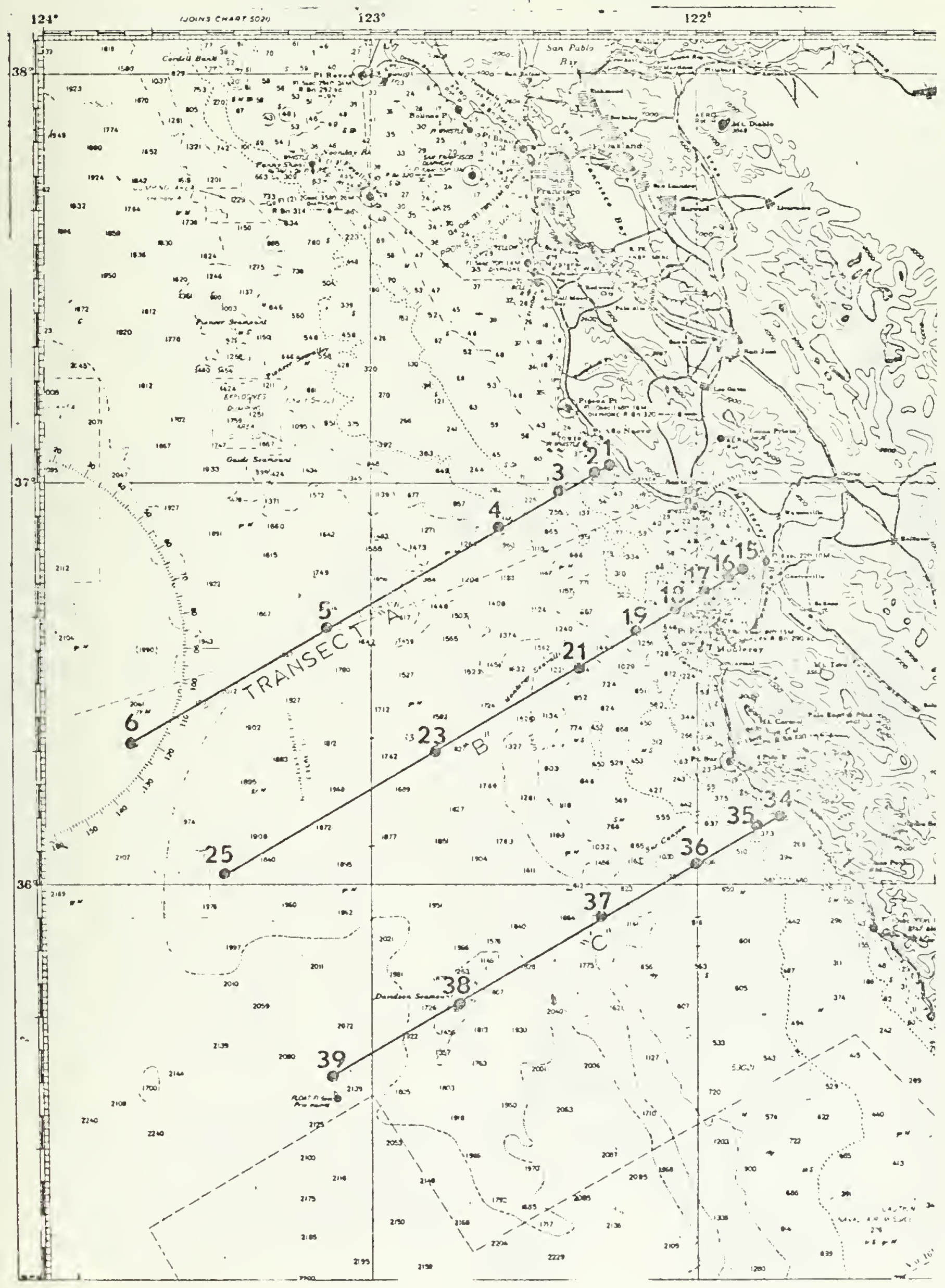





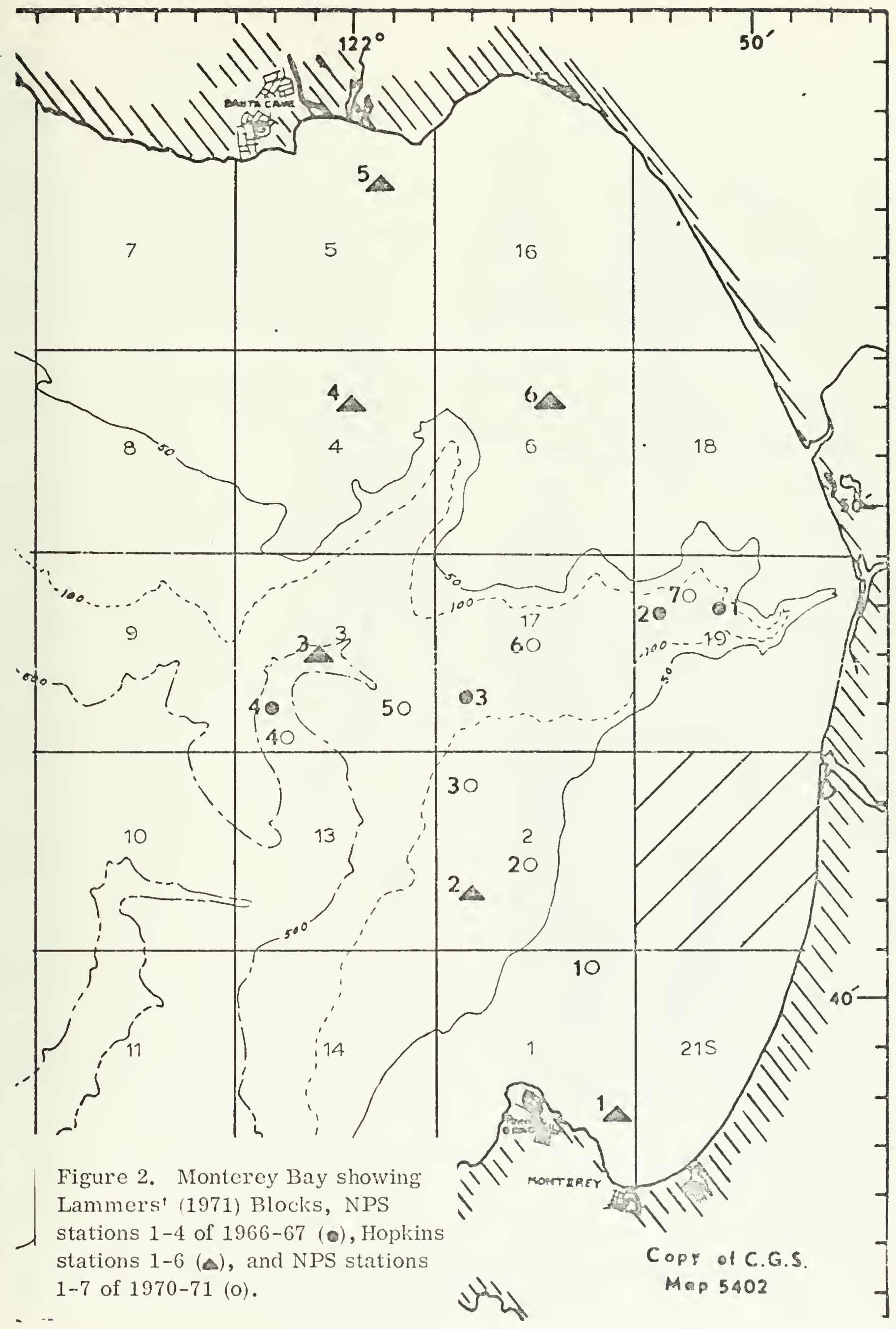





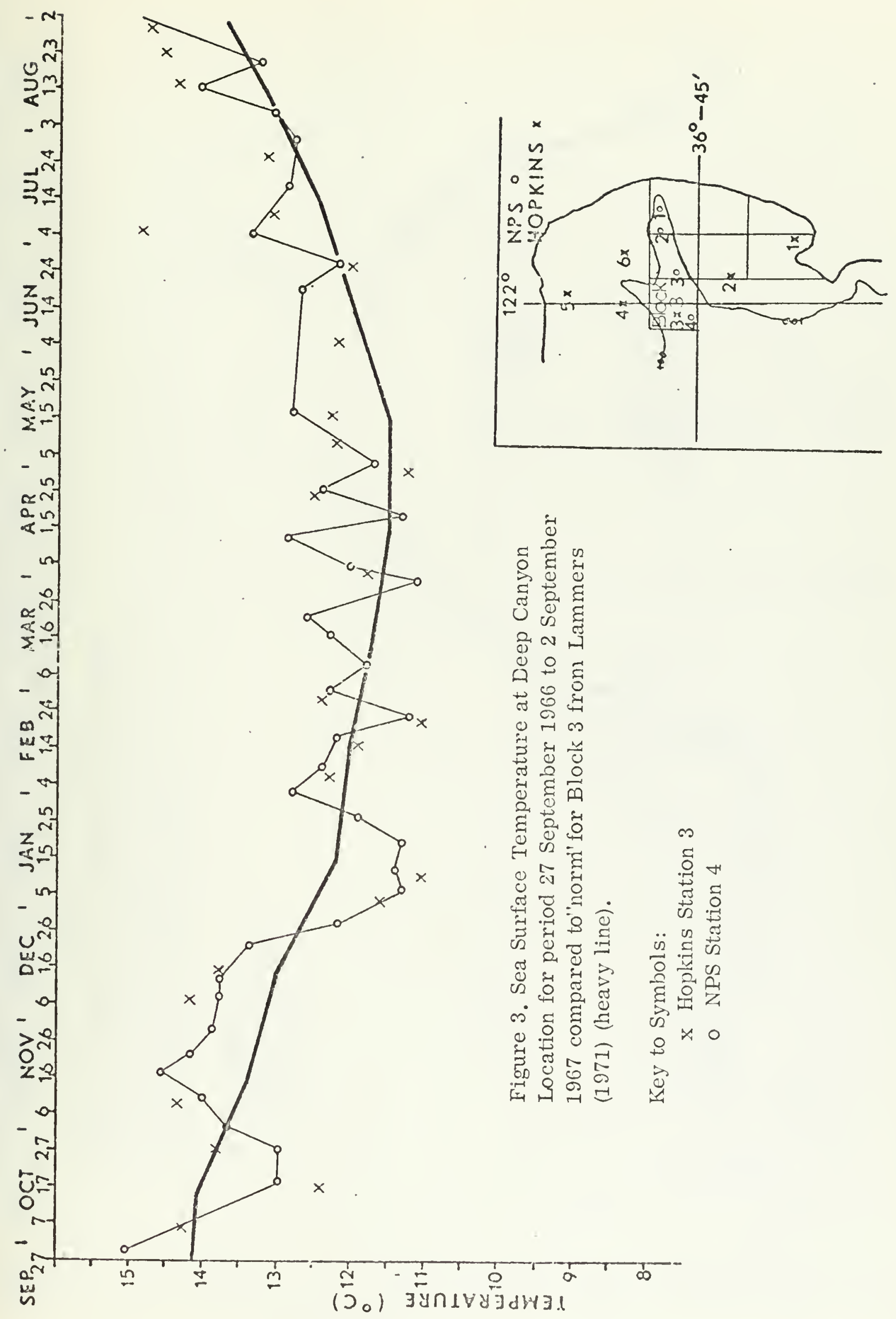




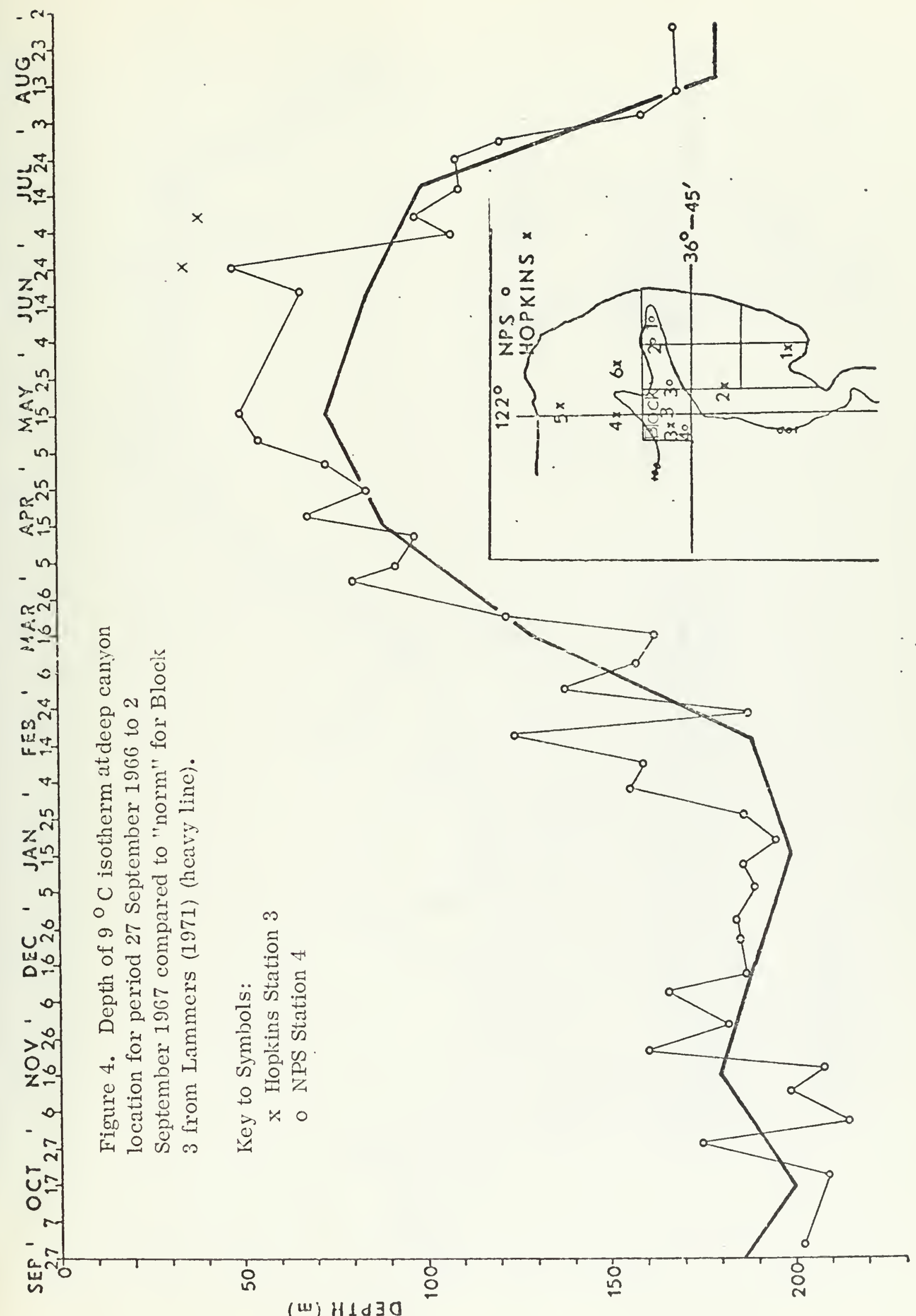





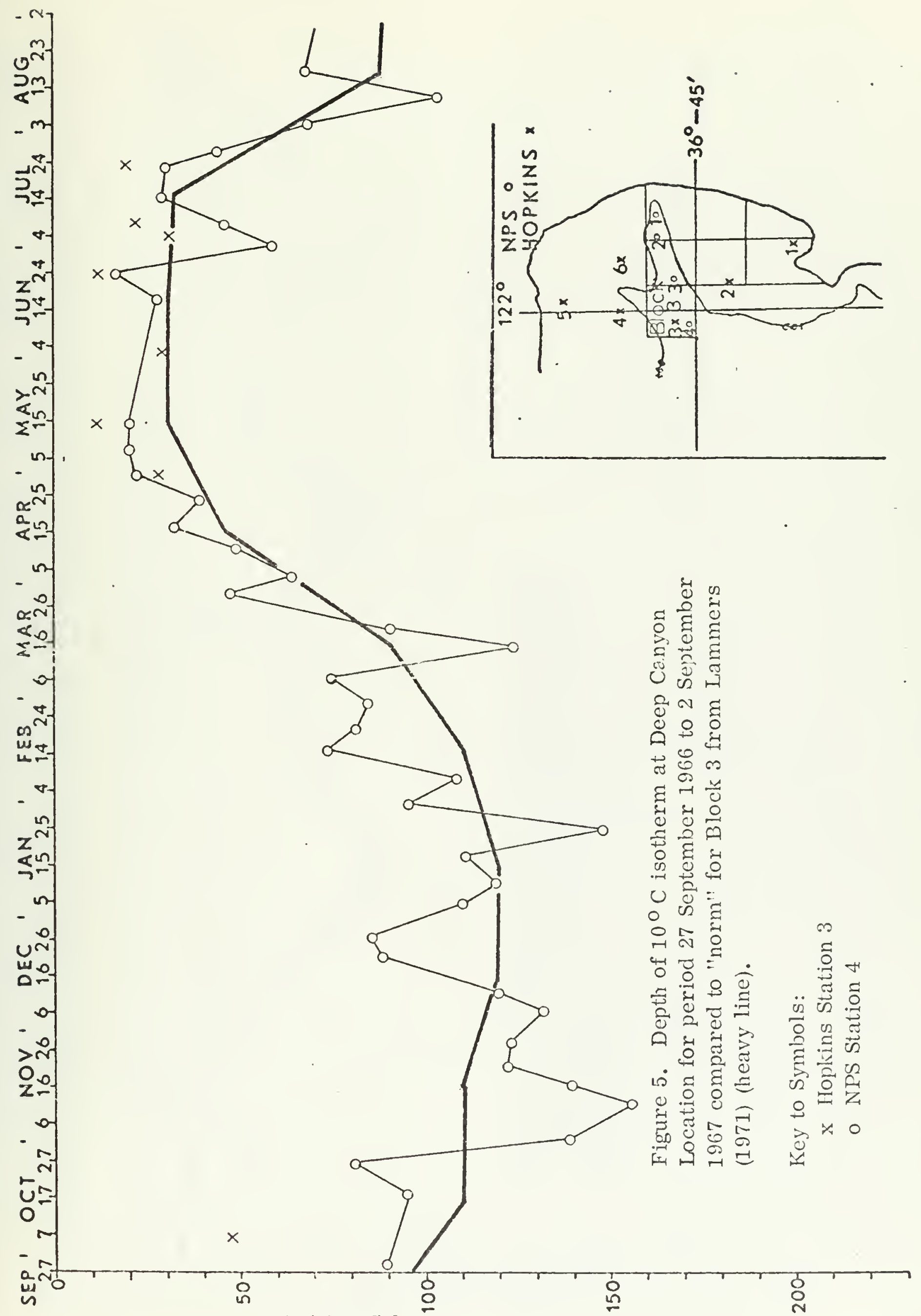

(w) $\mathrm{H} \perp \mathrm{d} 3 \mathrm{O}$ 



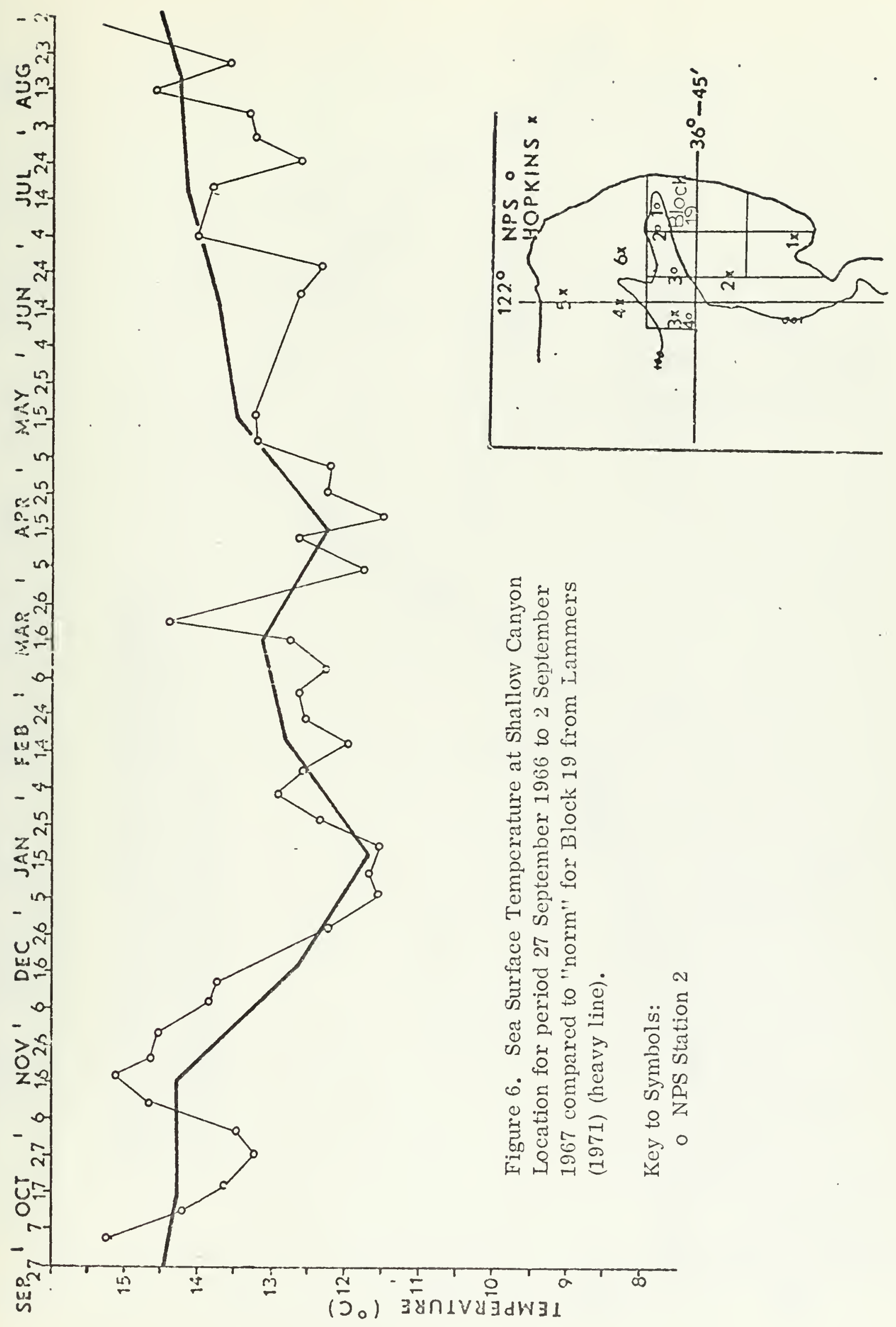





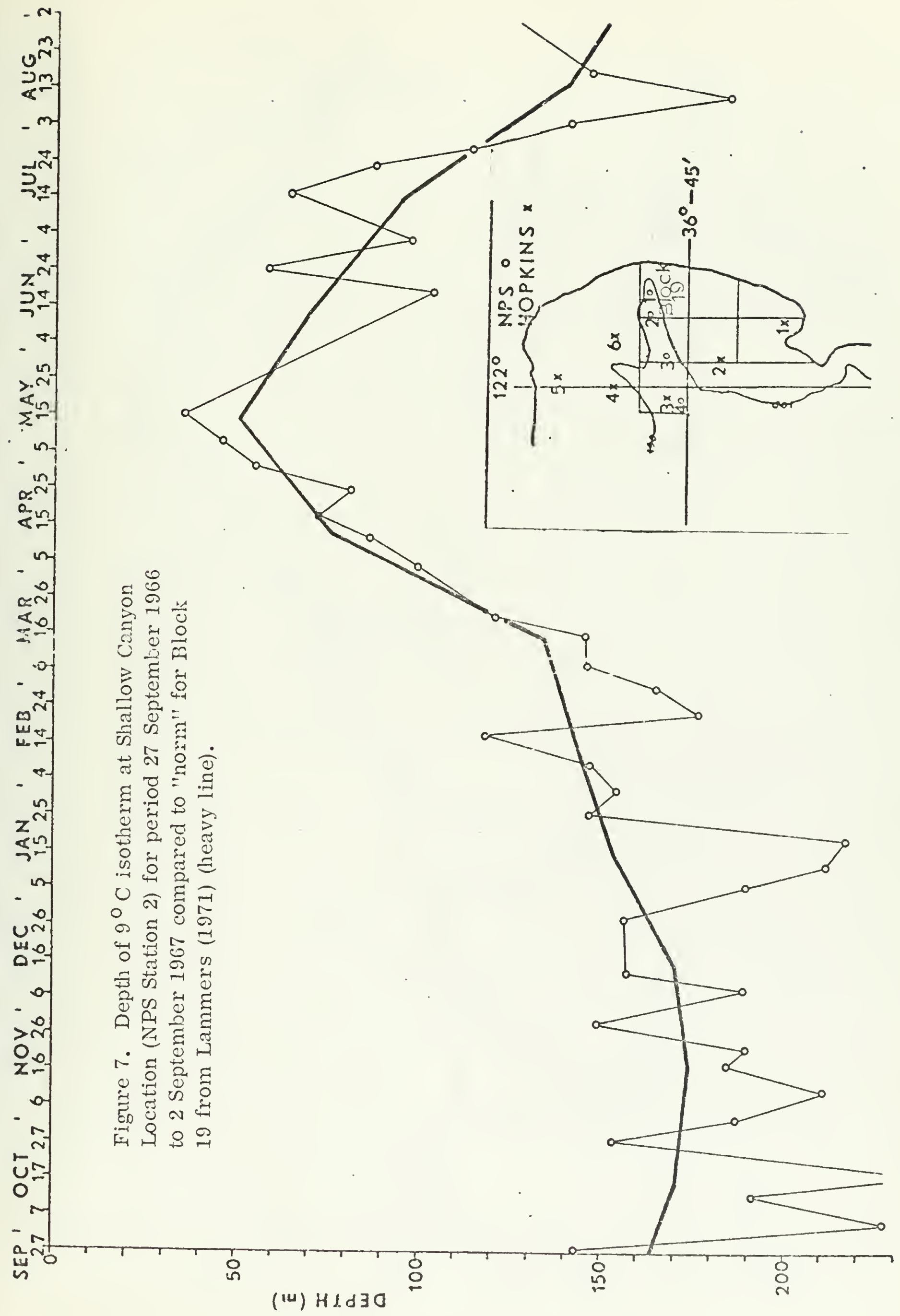





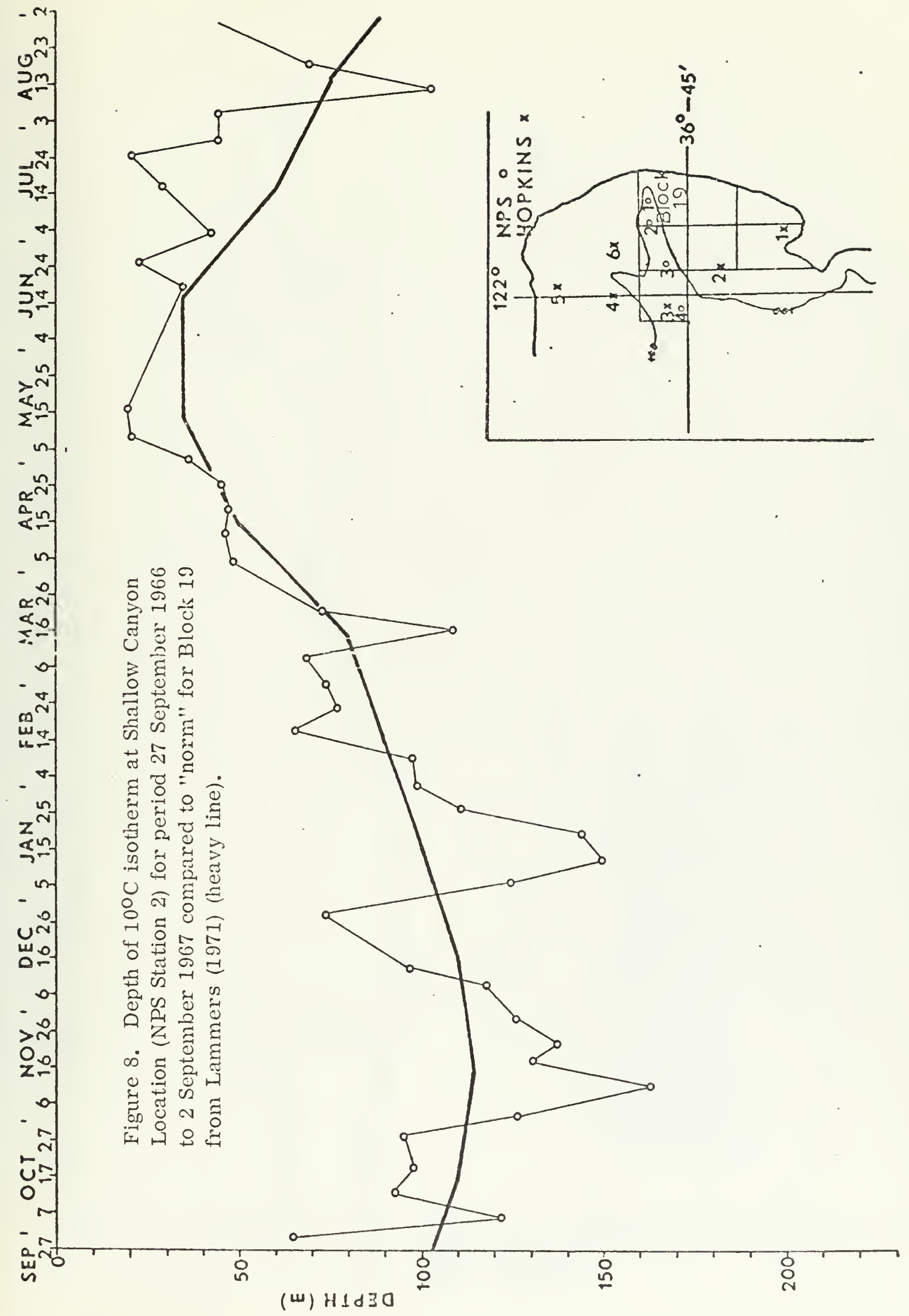





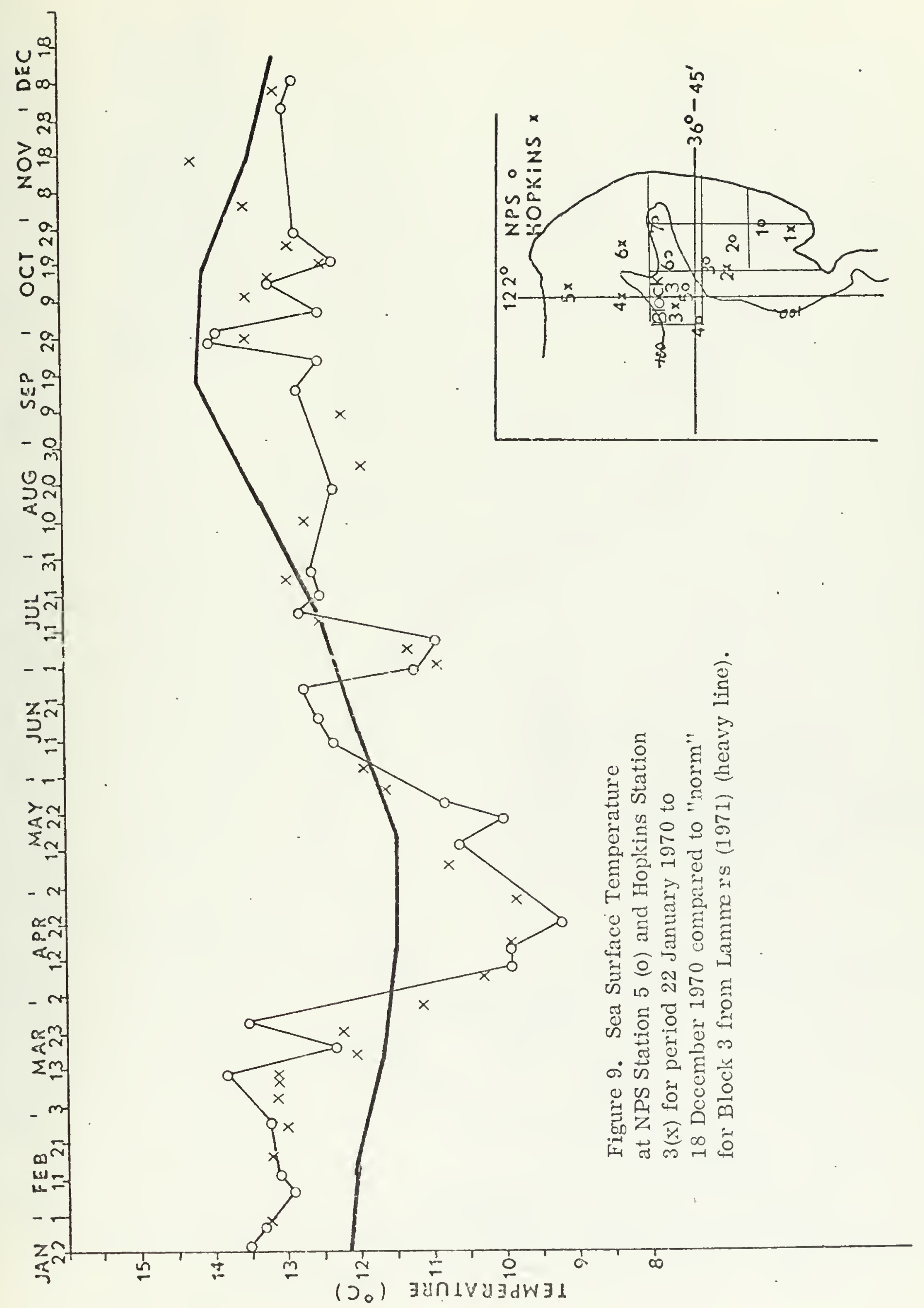





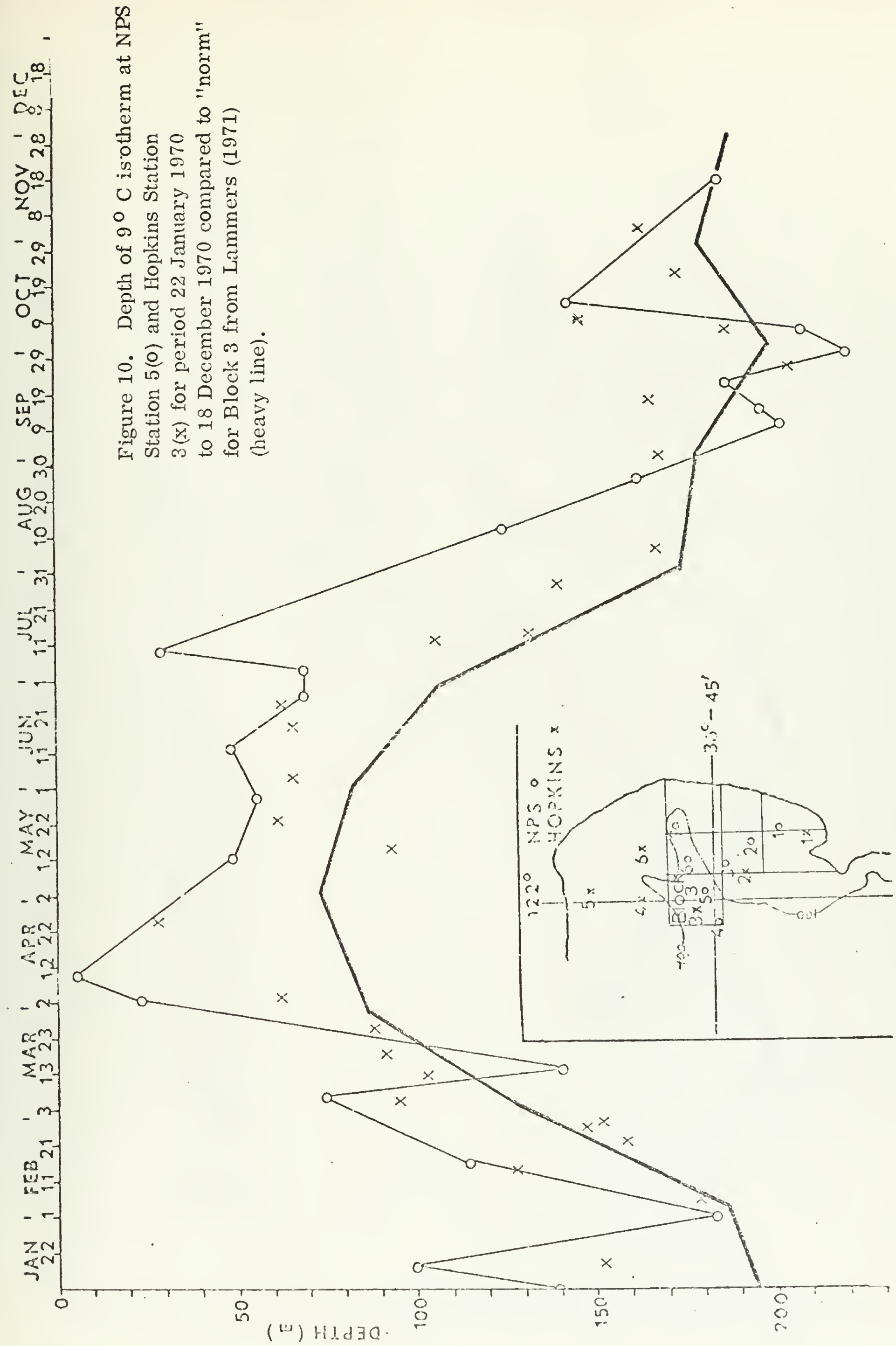





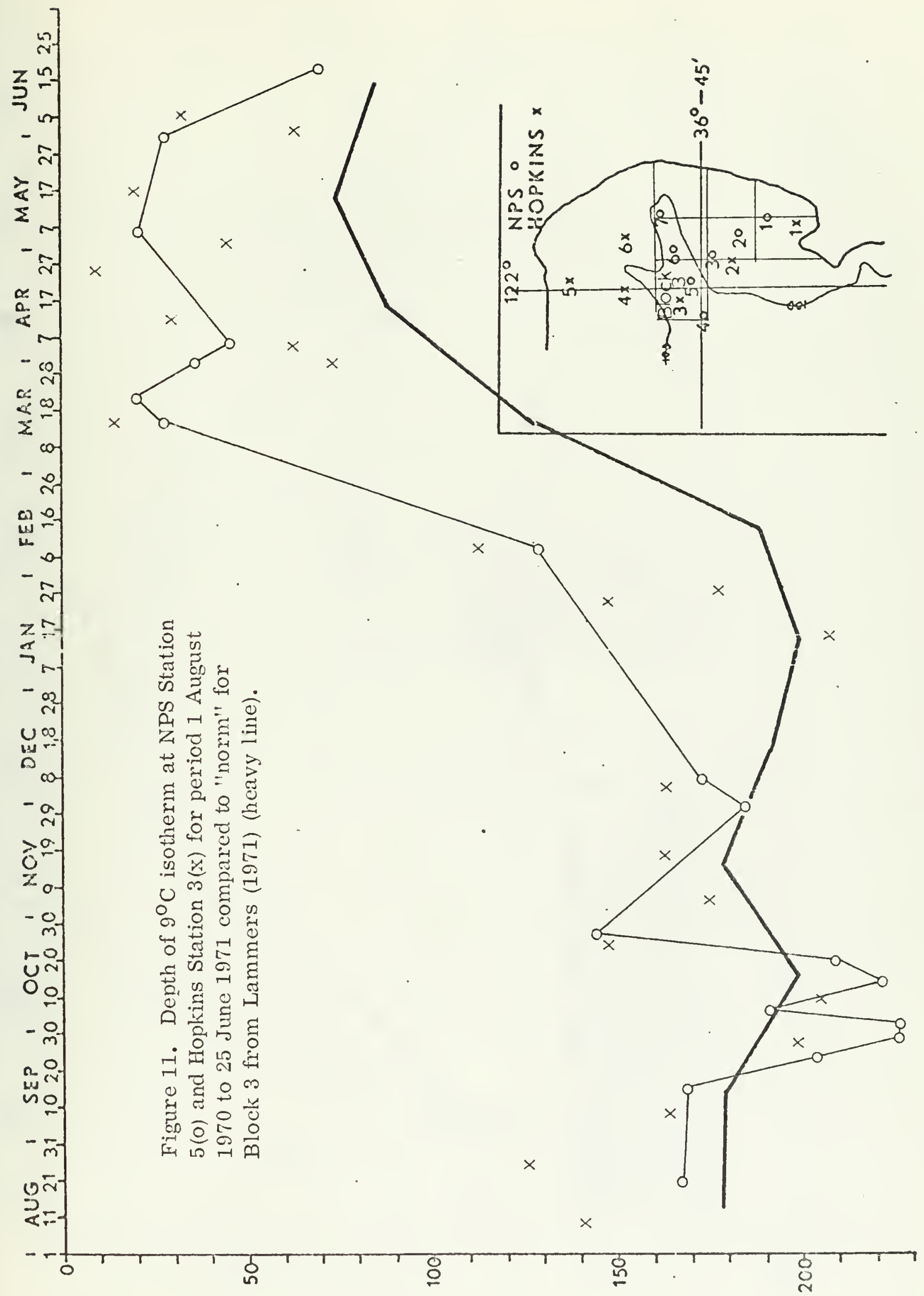

(w) $H \mathrm{~d} 30$ 



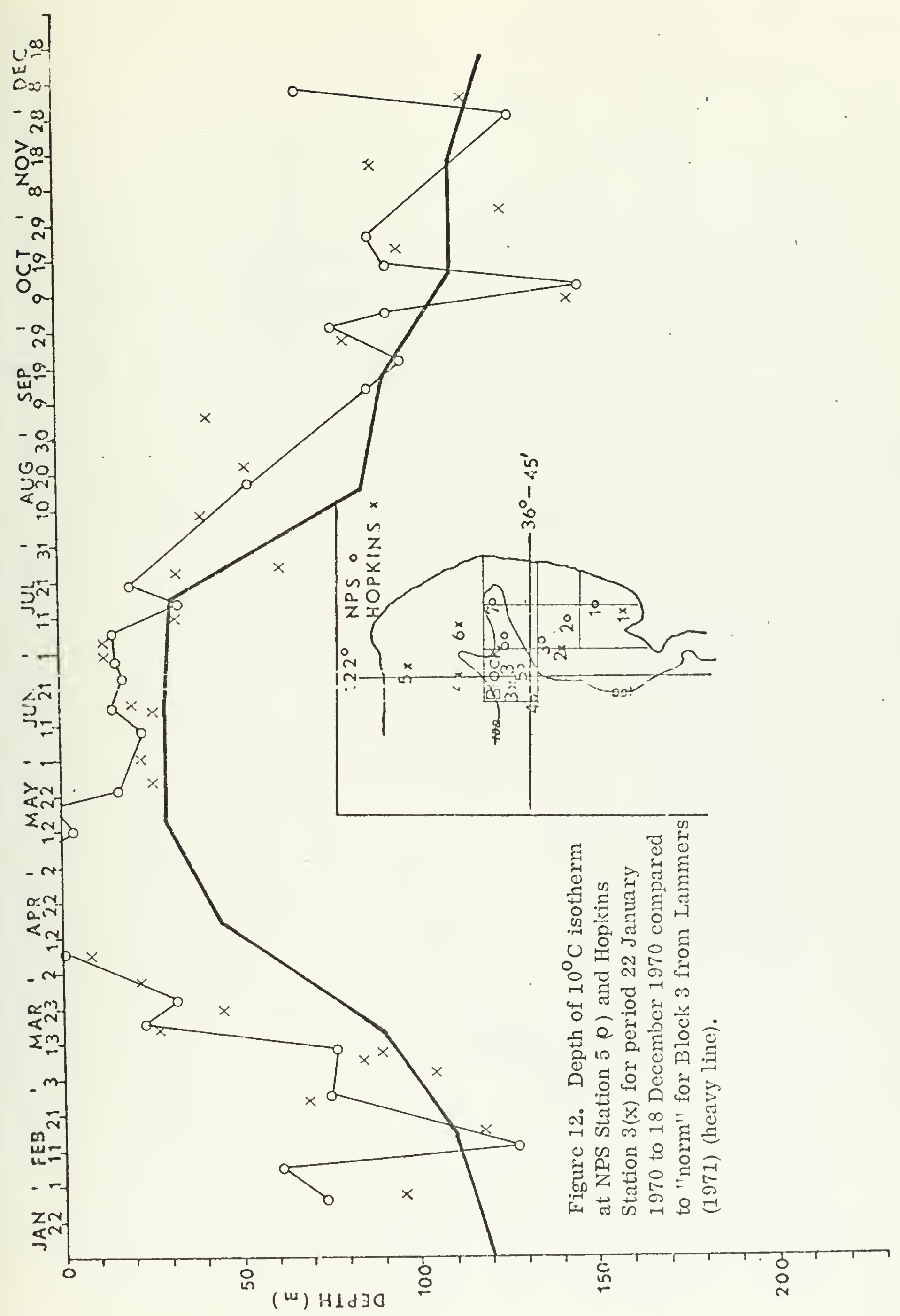





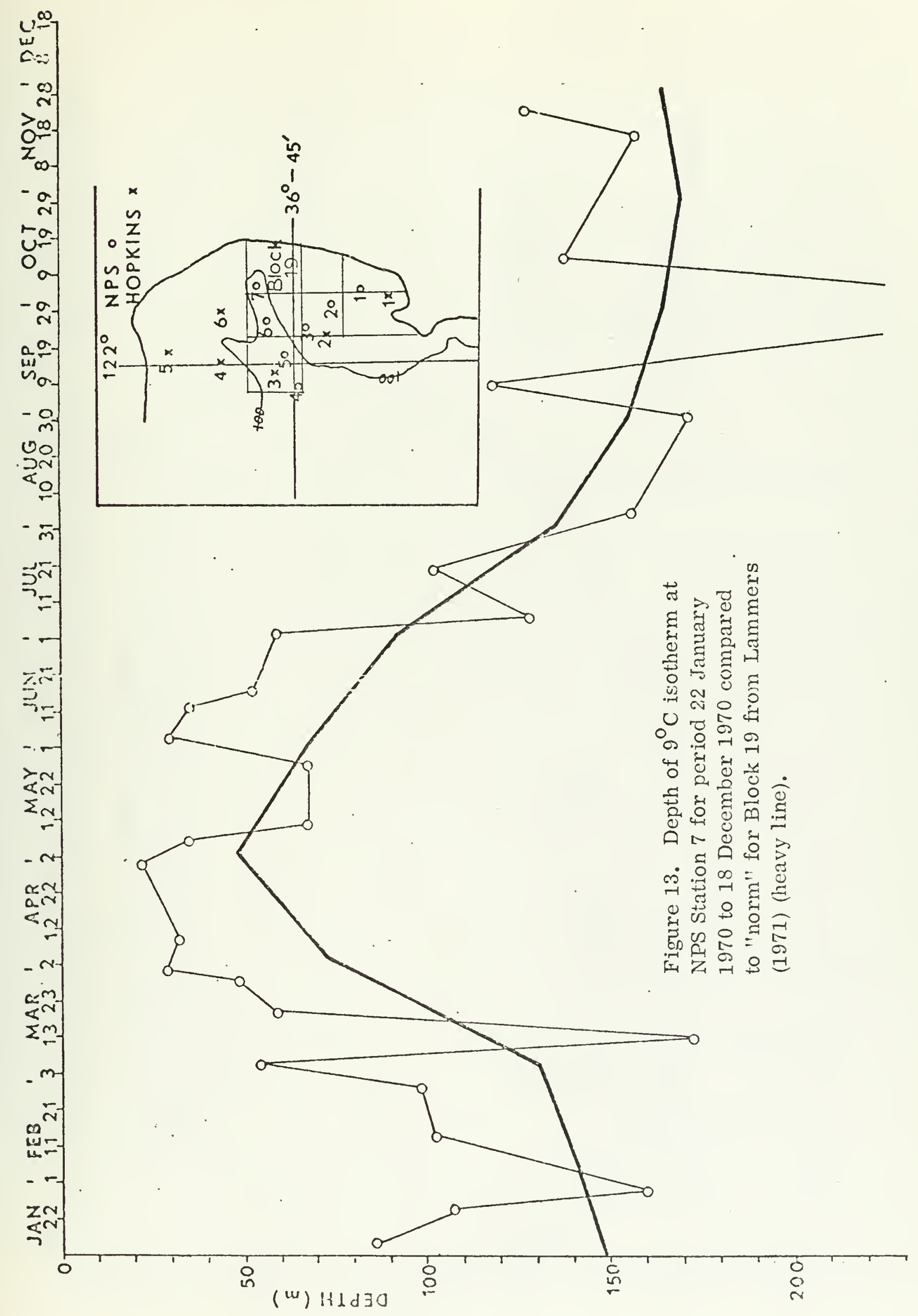





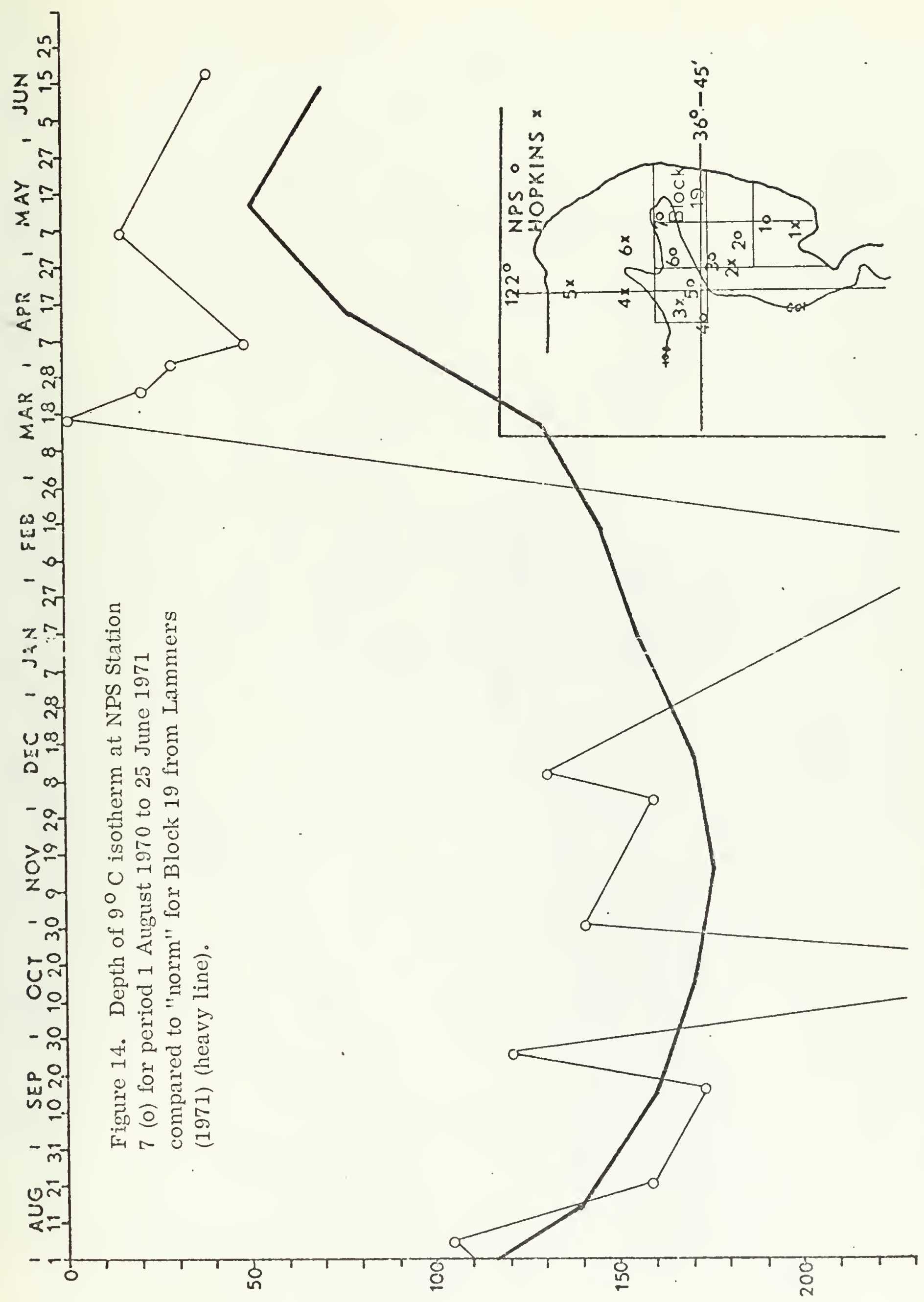

(w) HLd 30 




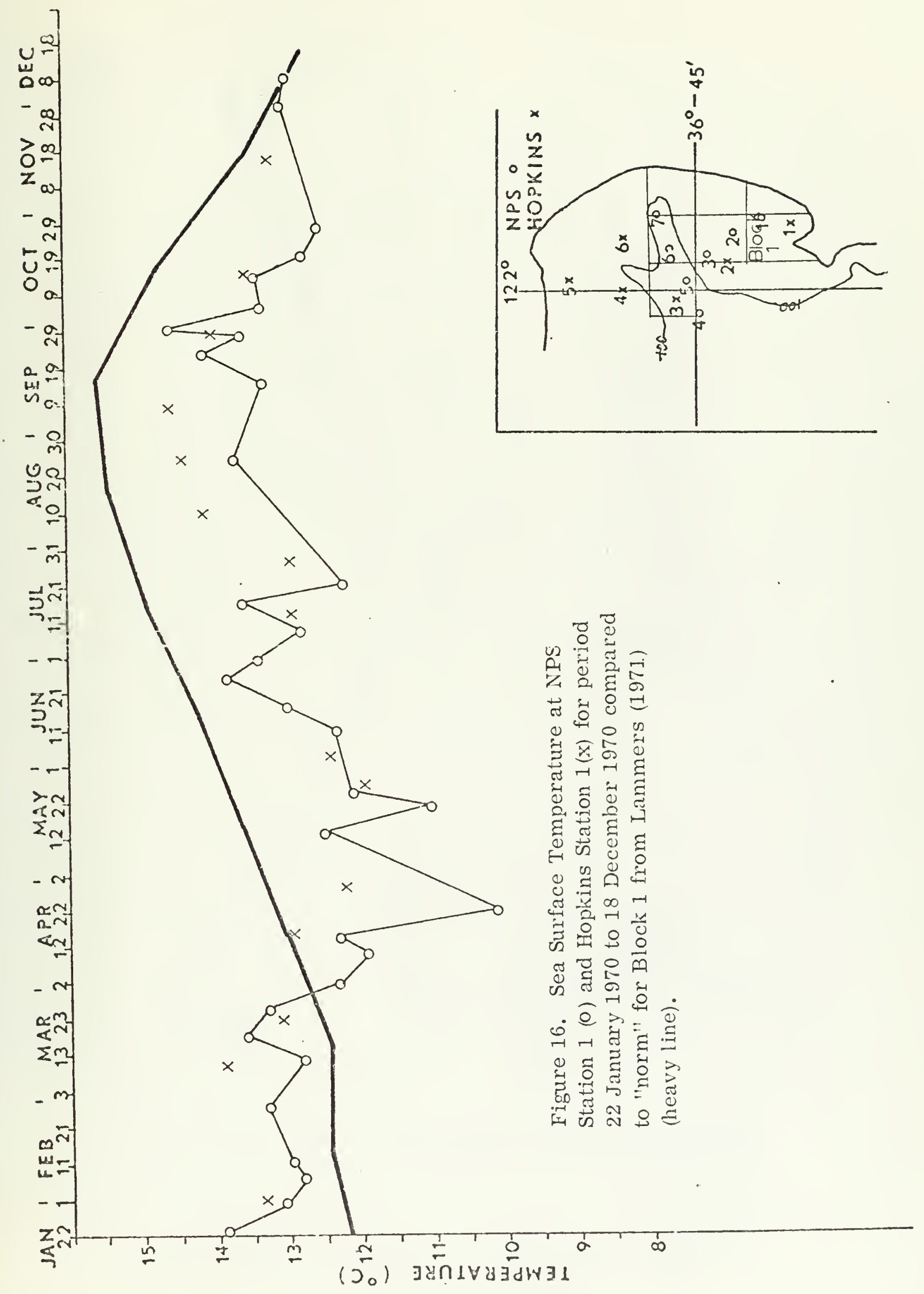





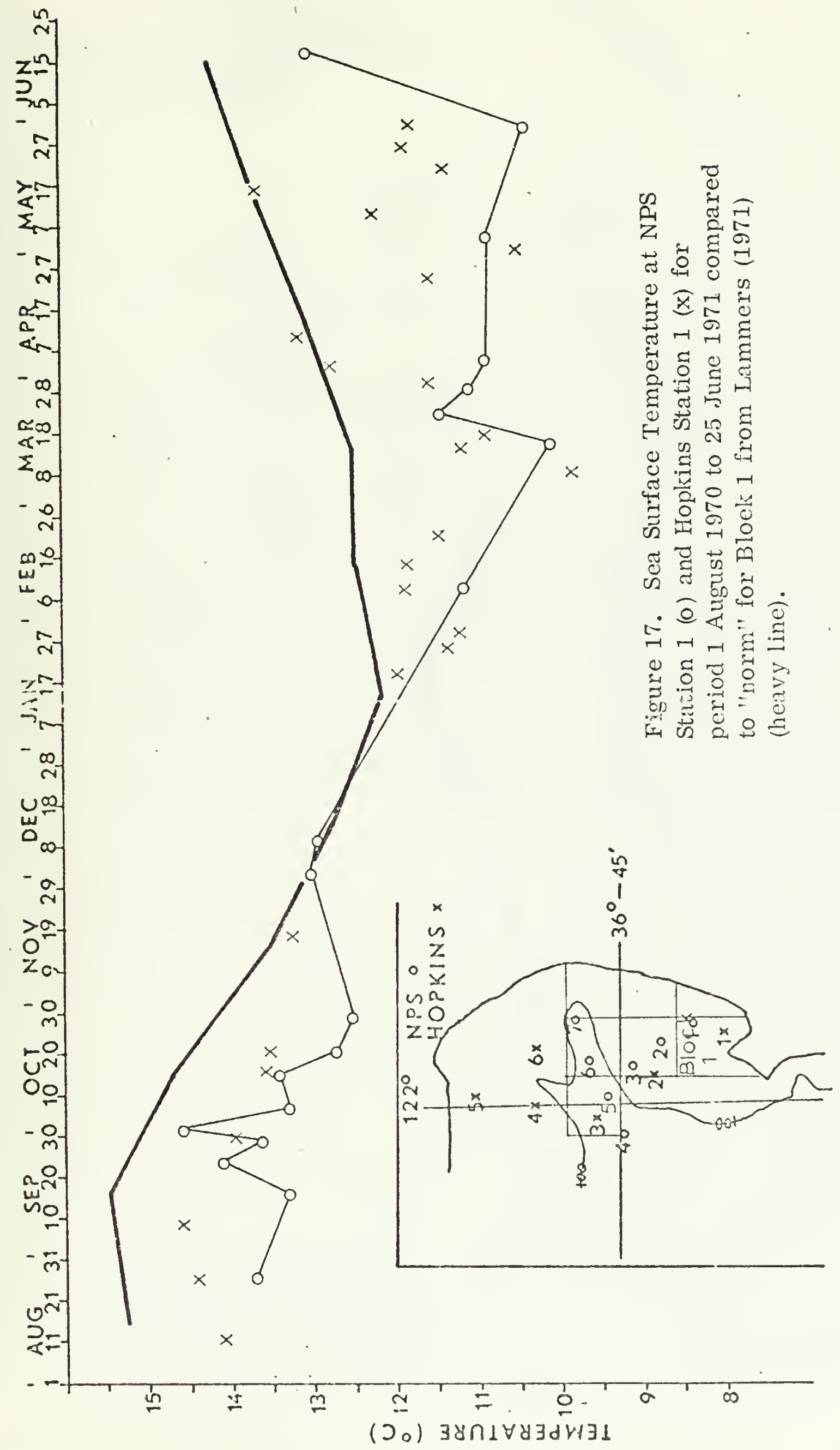





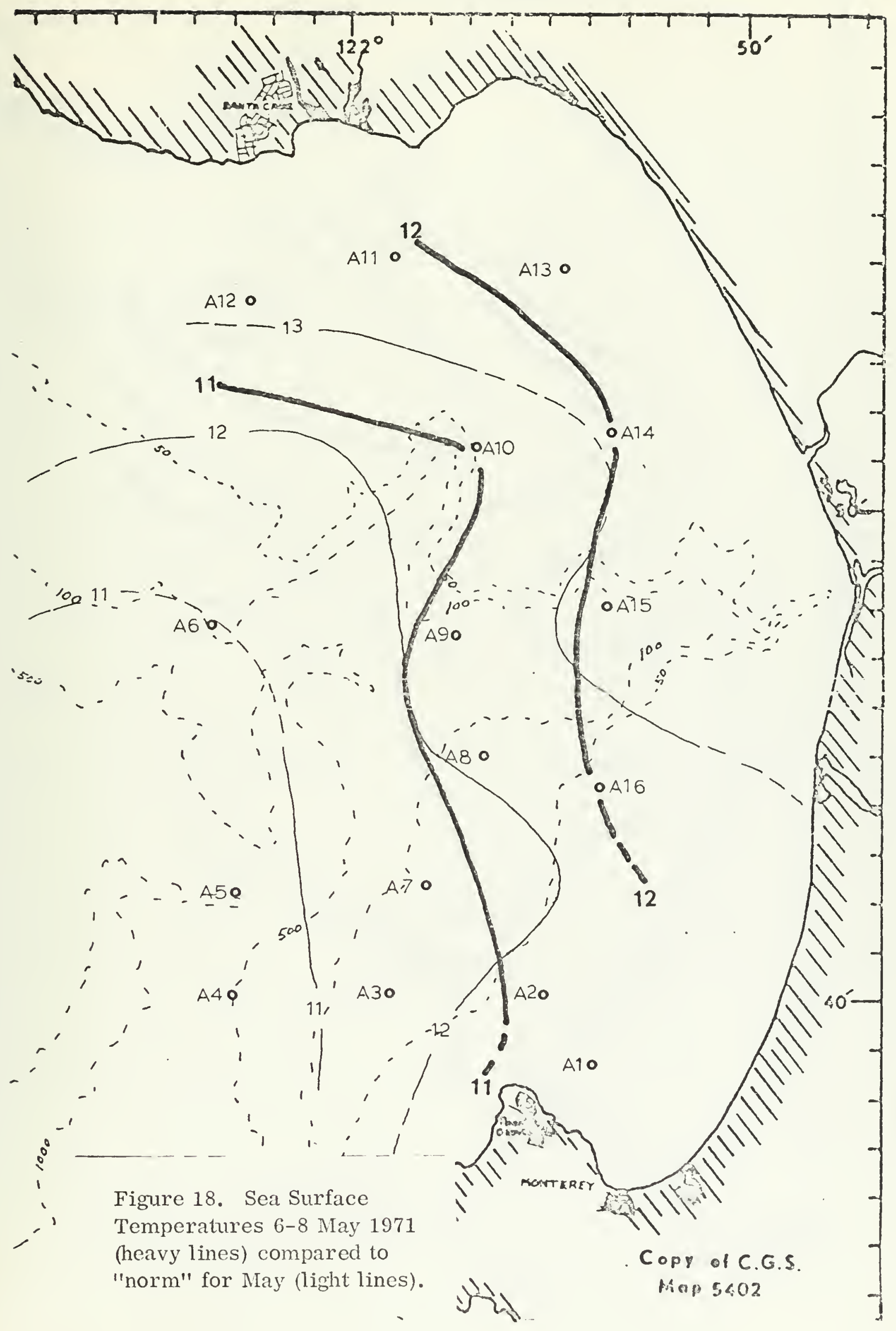







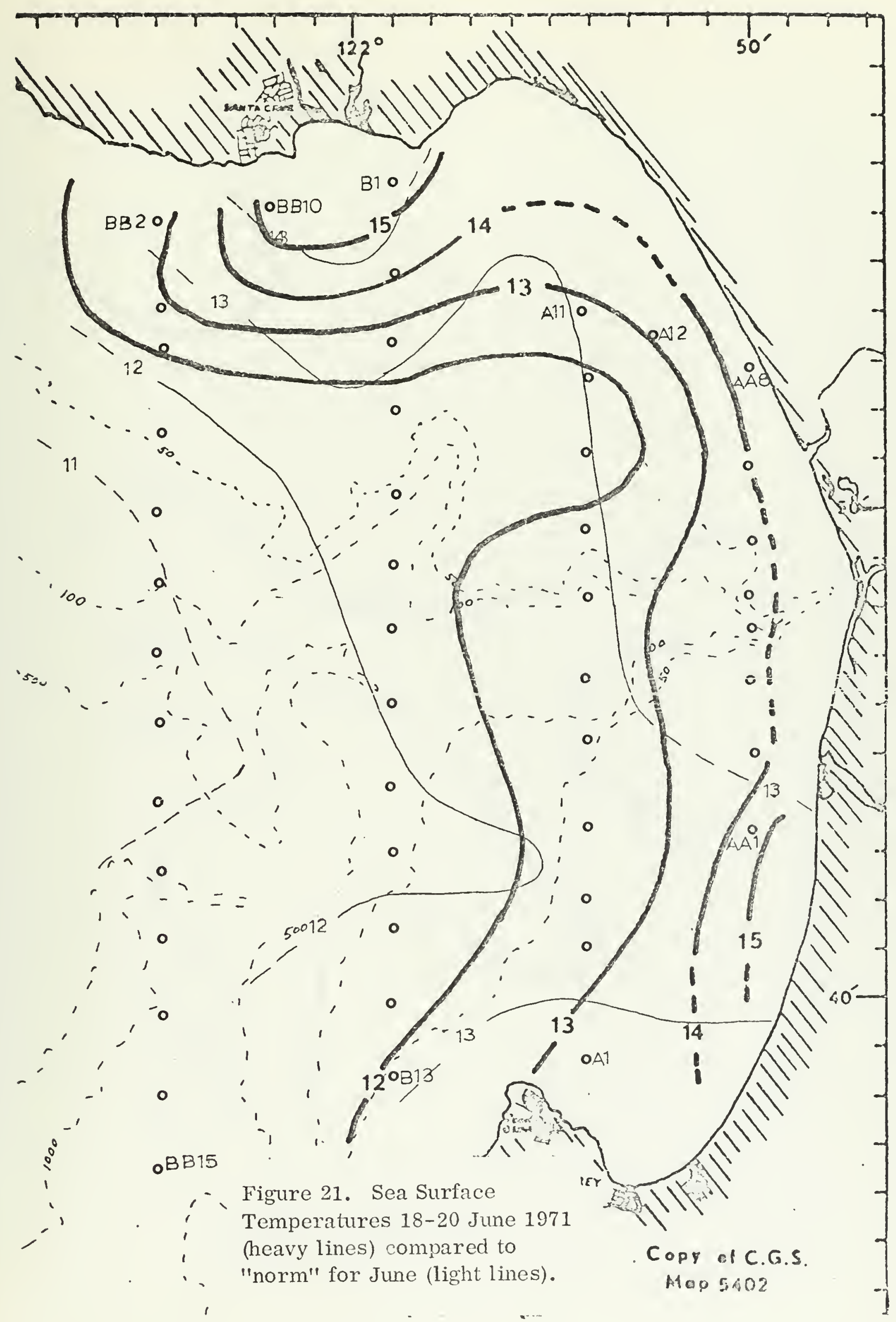





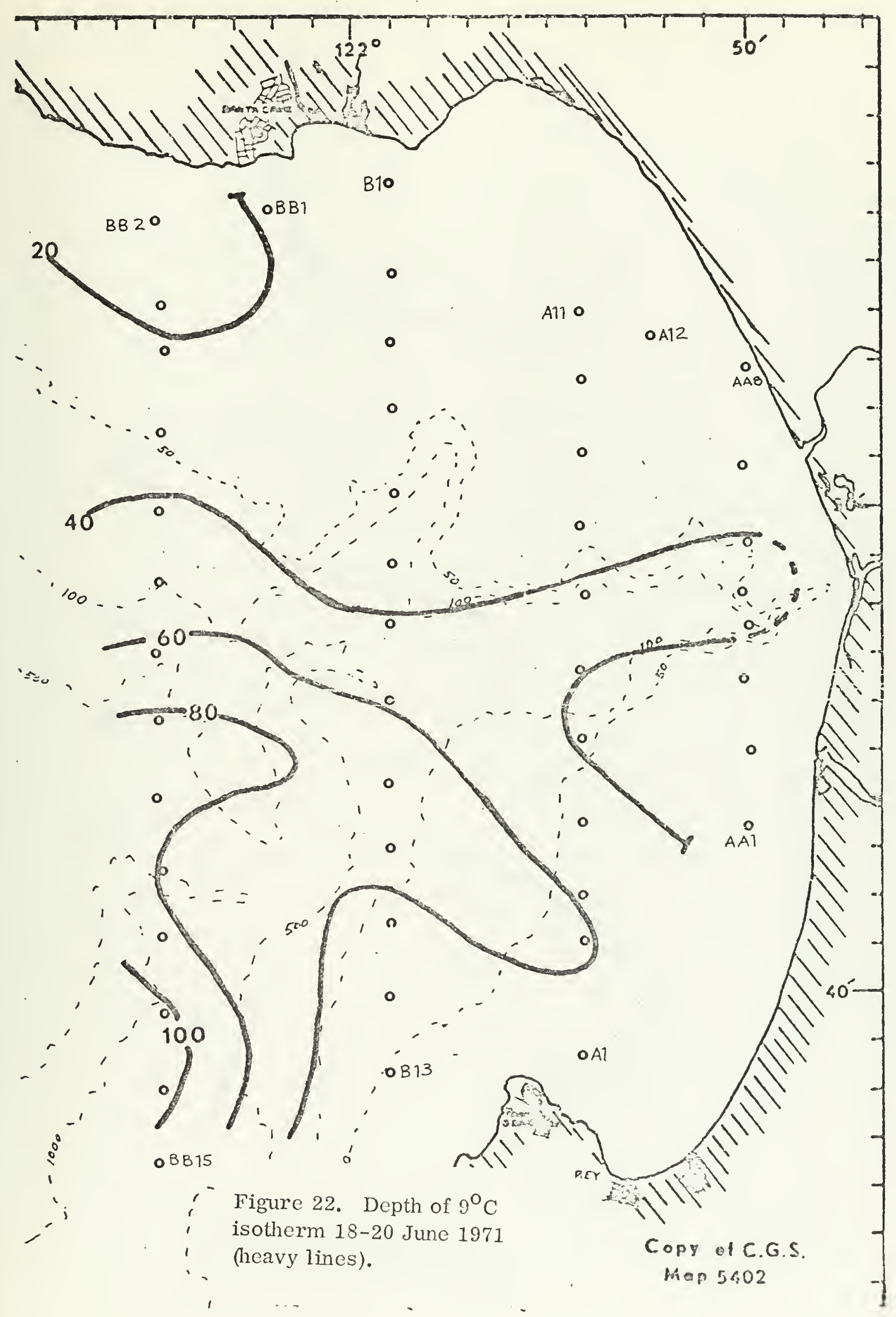





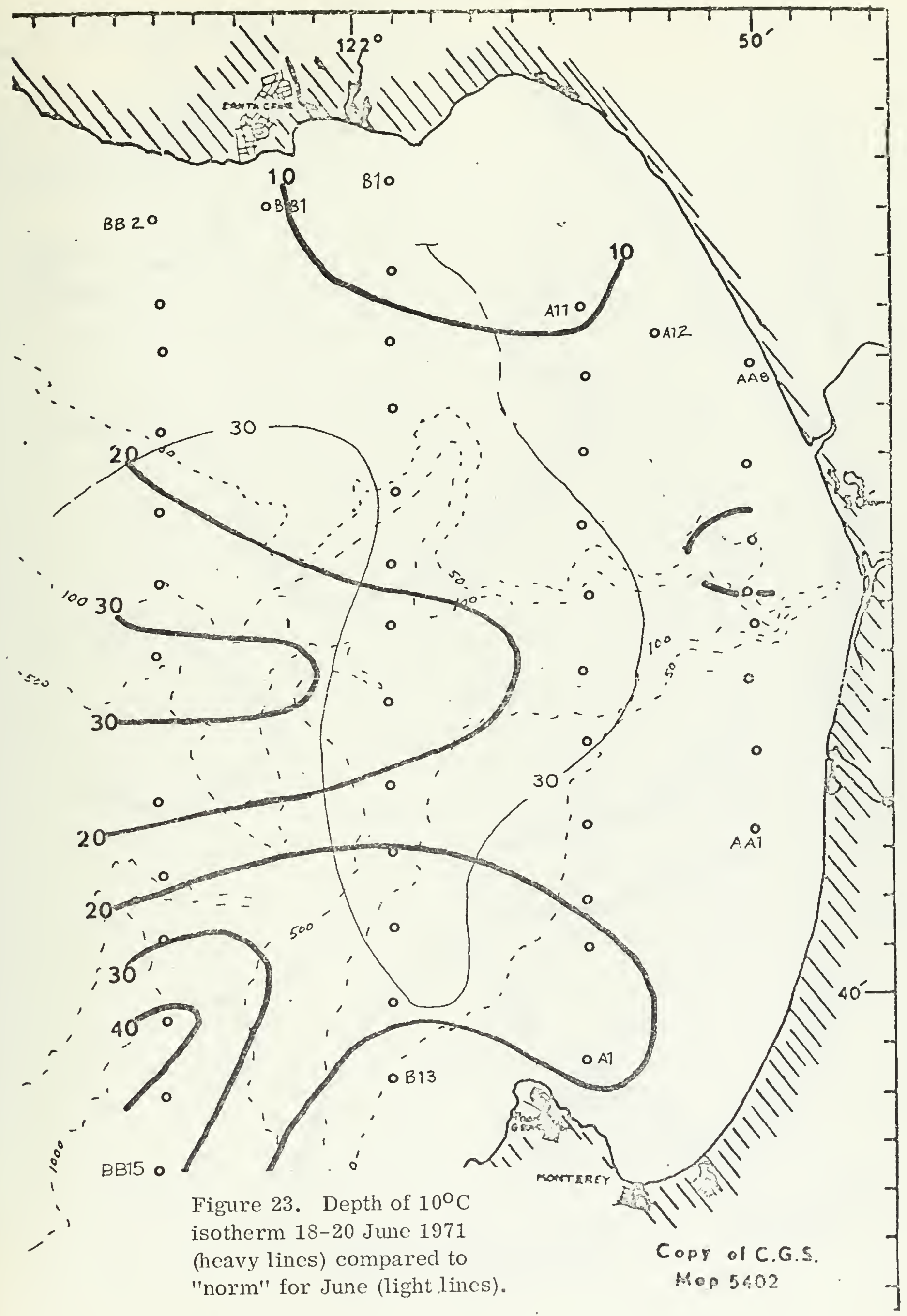





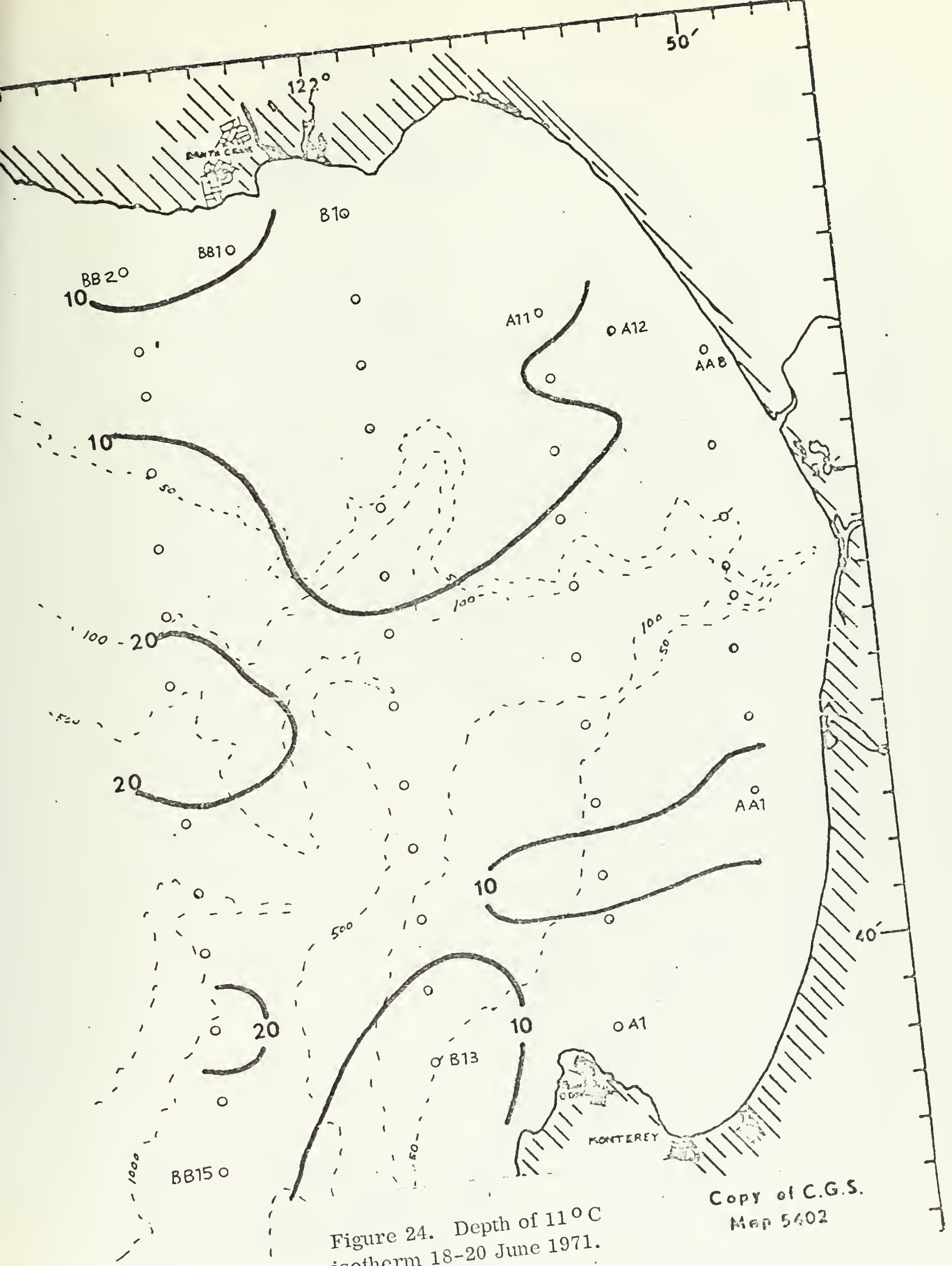





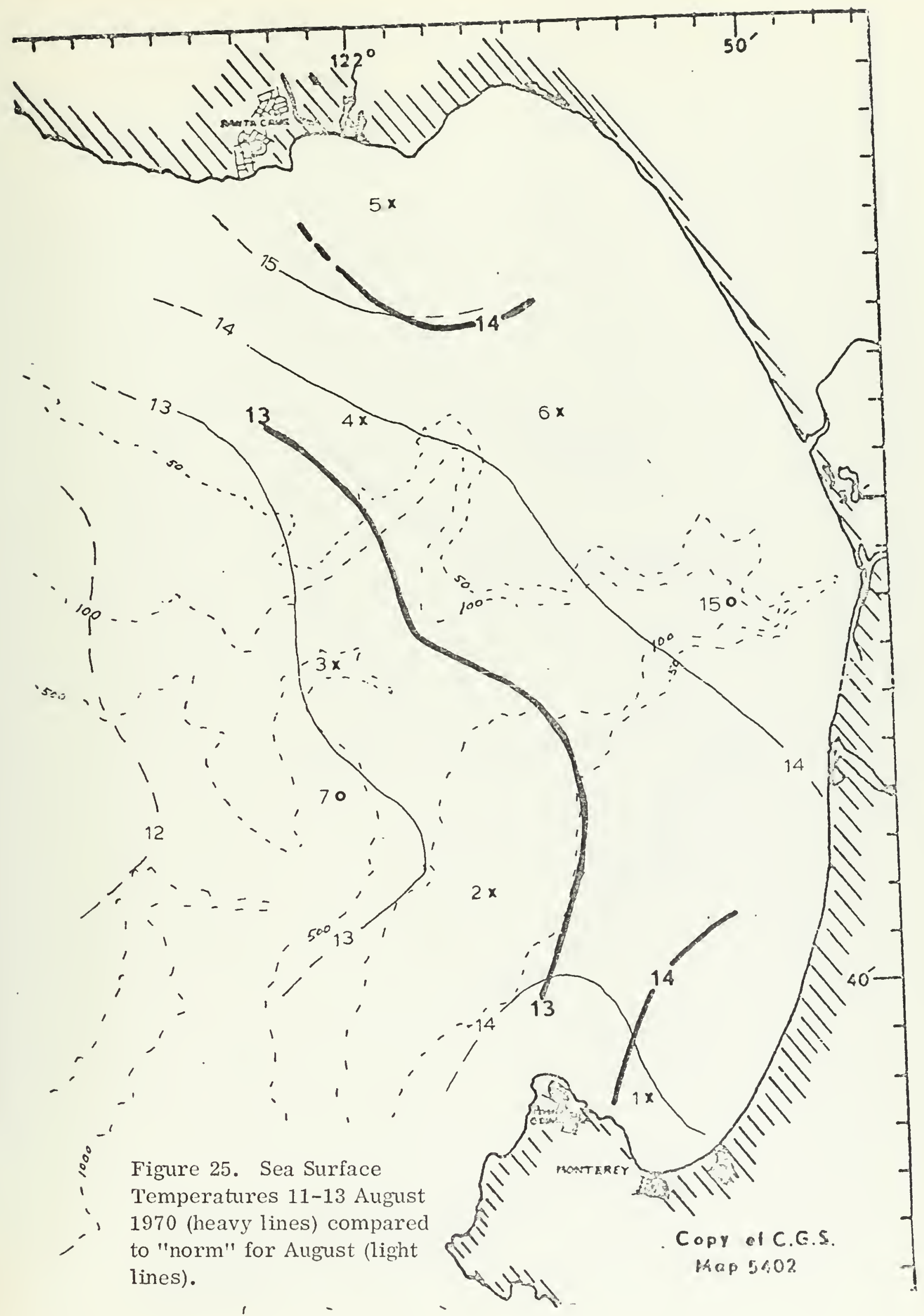





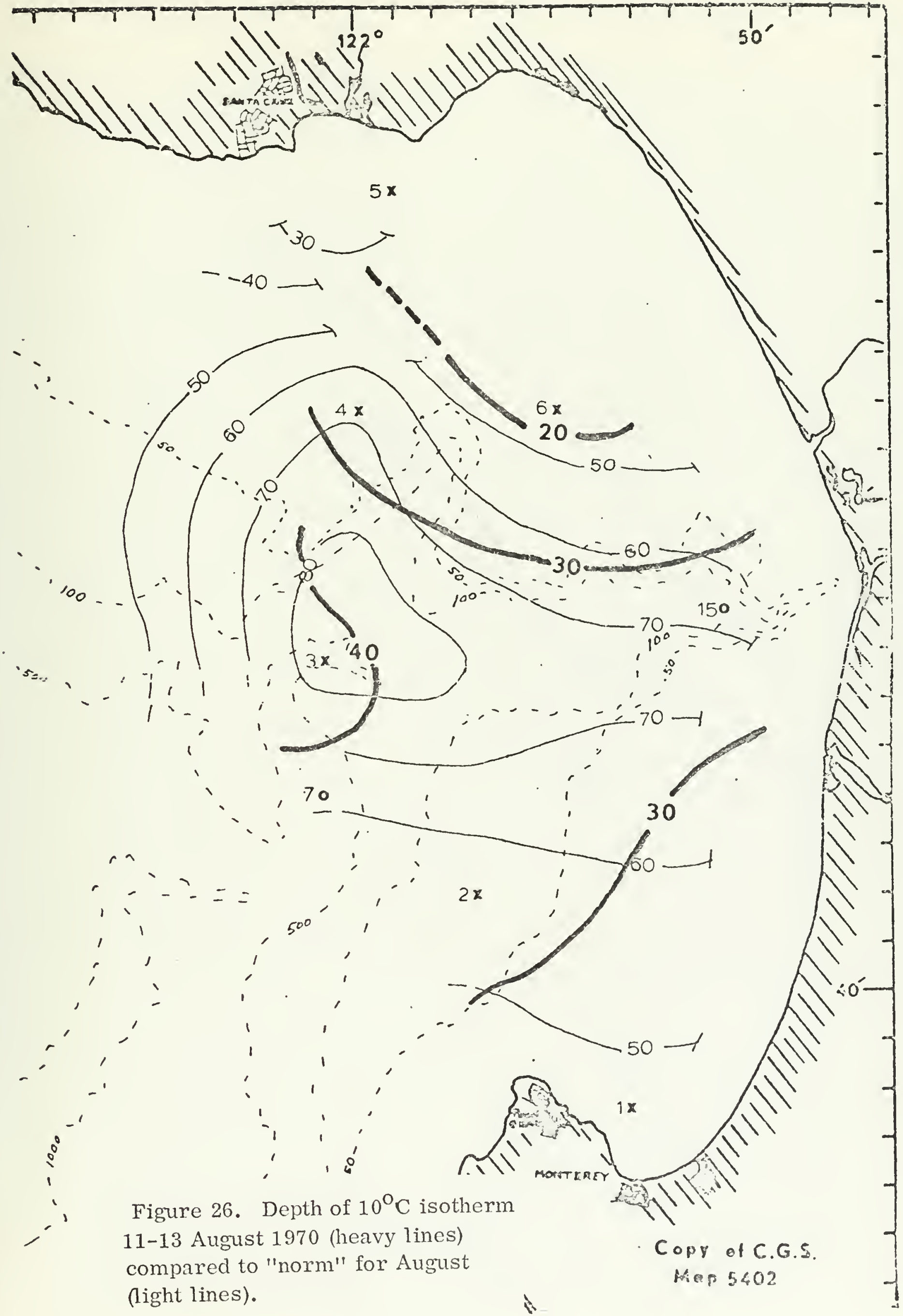





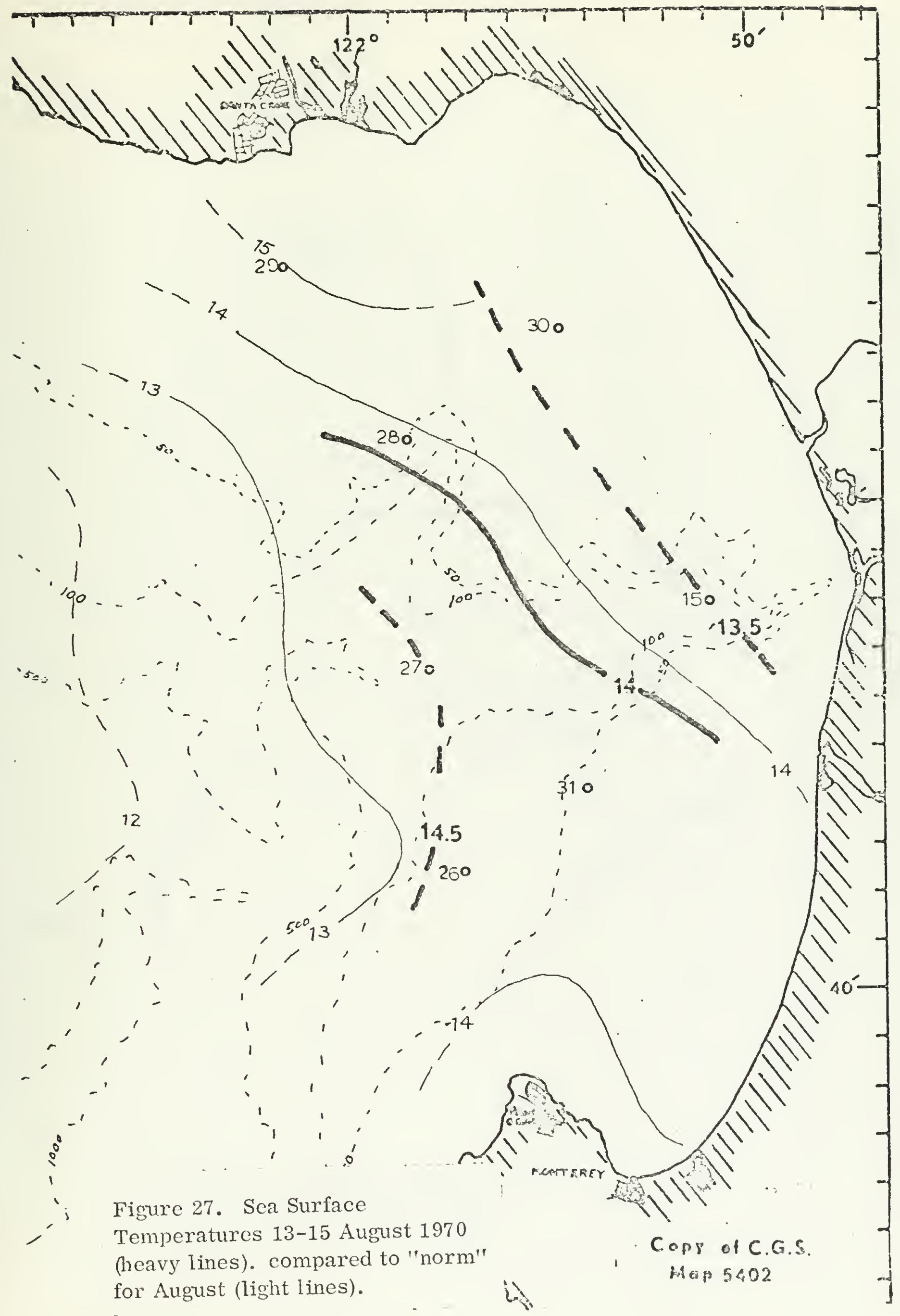






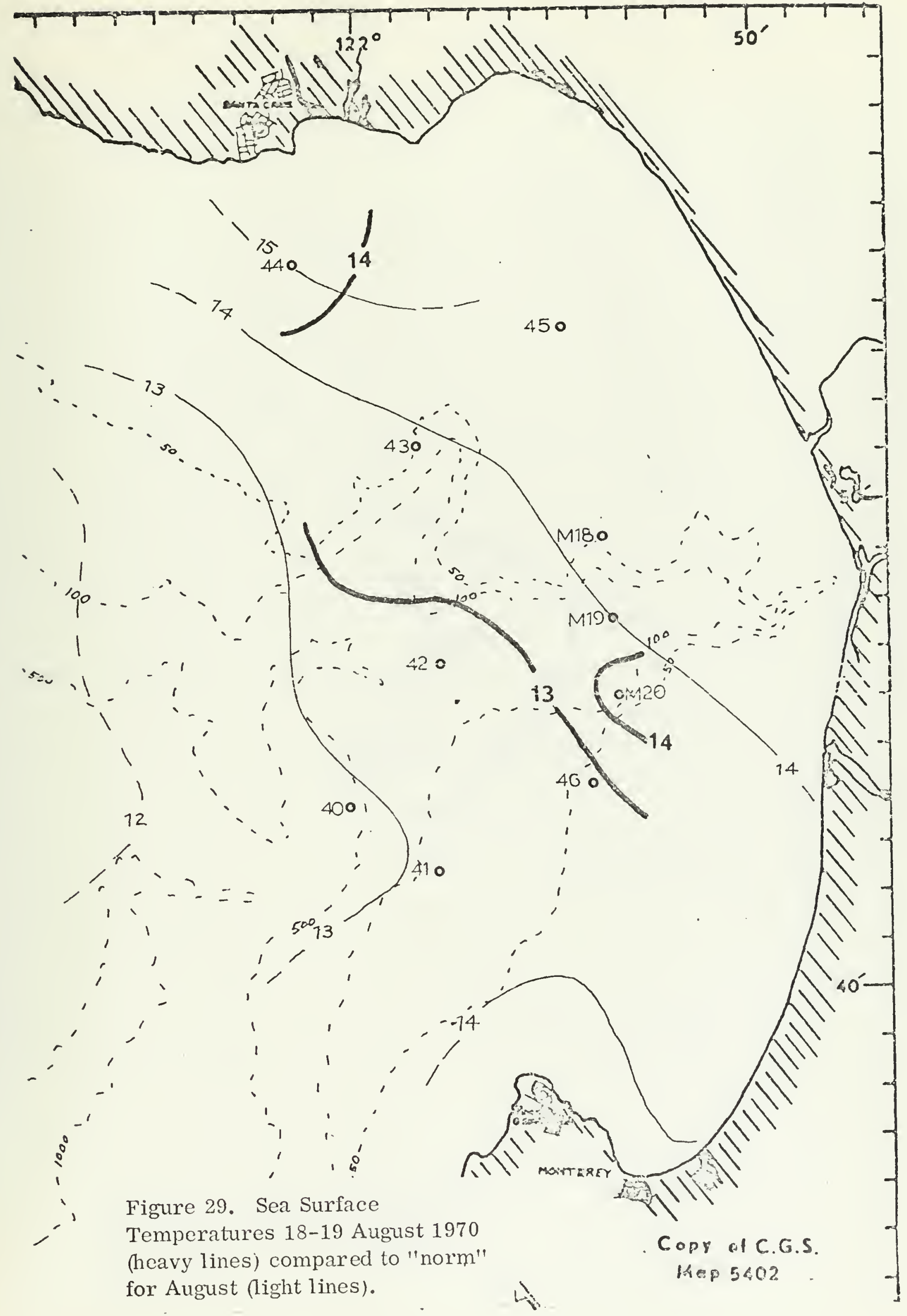




$$
\text { L. }
$$





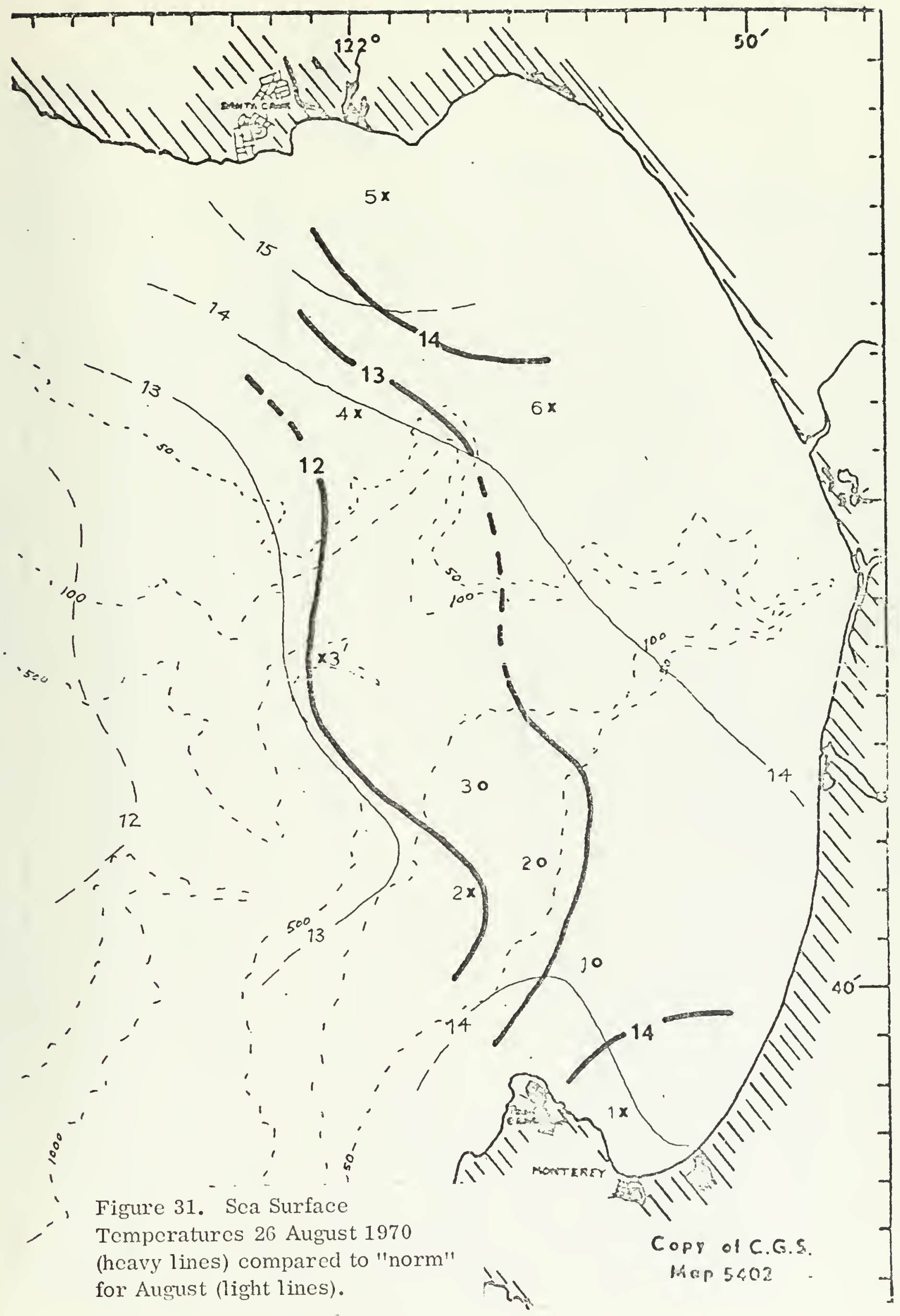





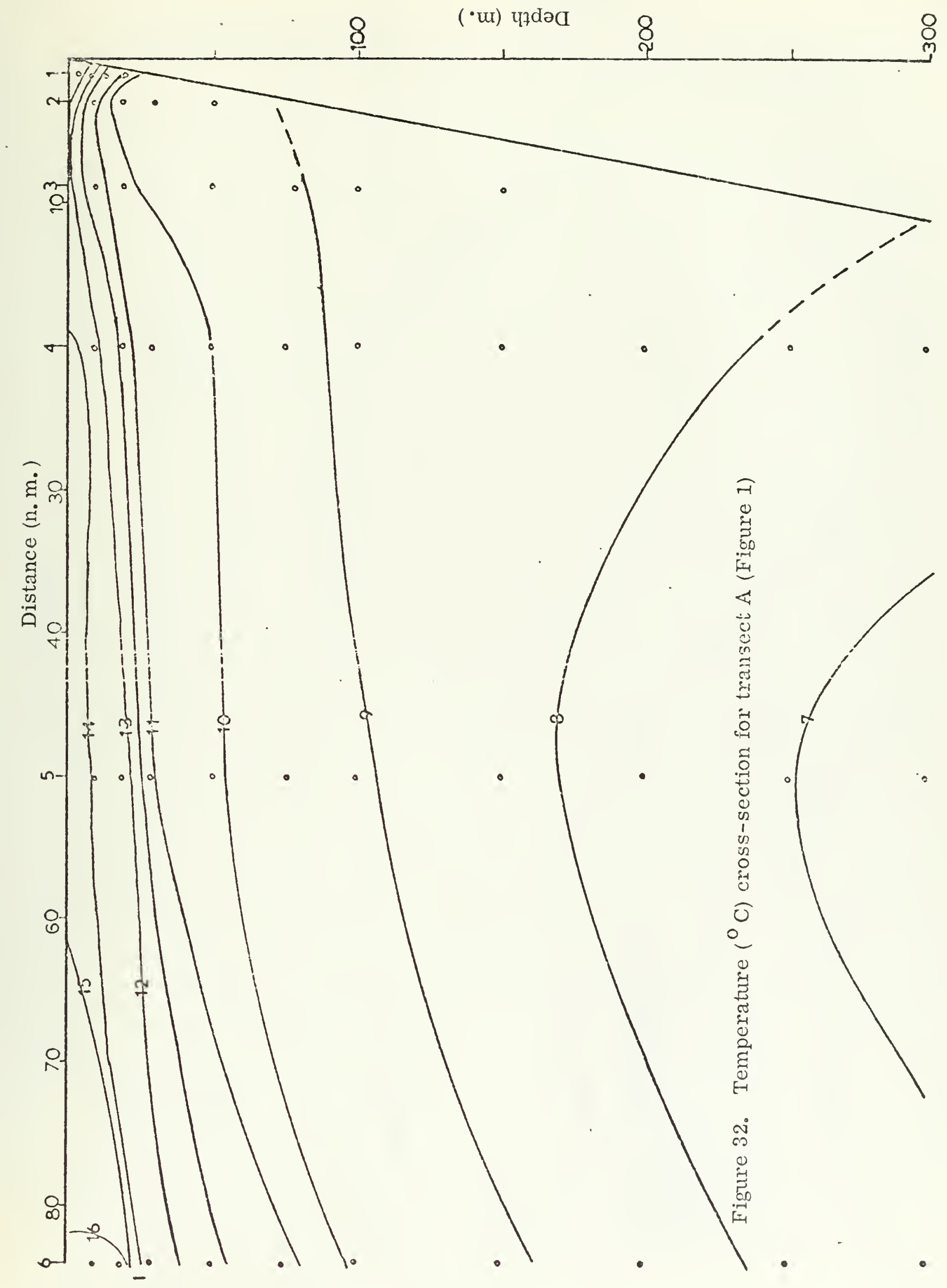



$8 \quad$ ('m) чาณว

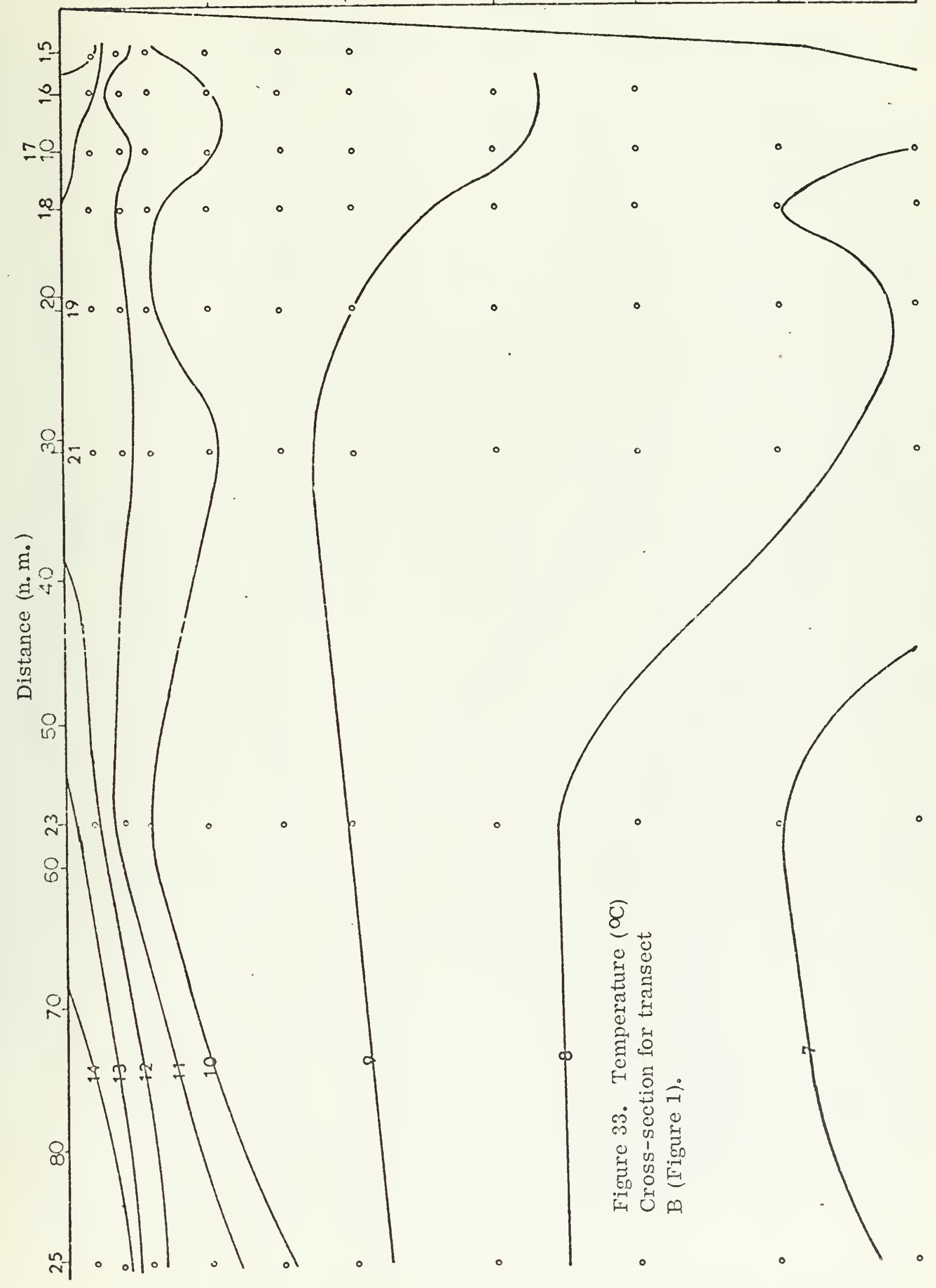





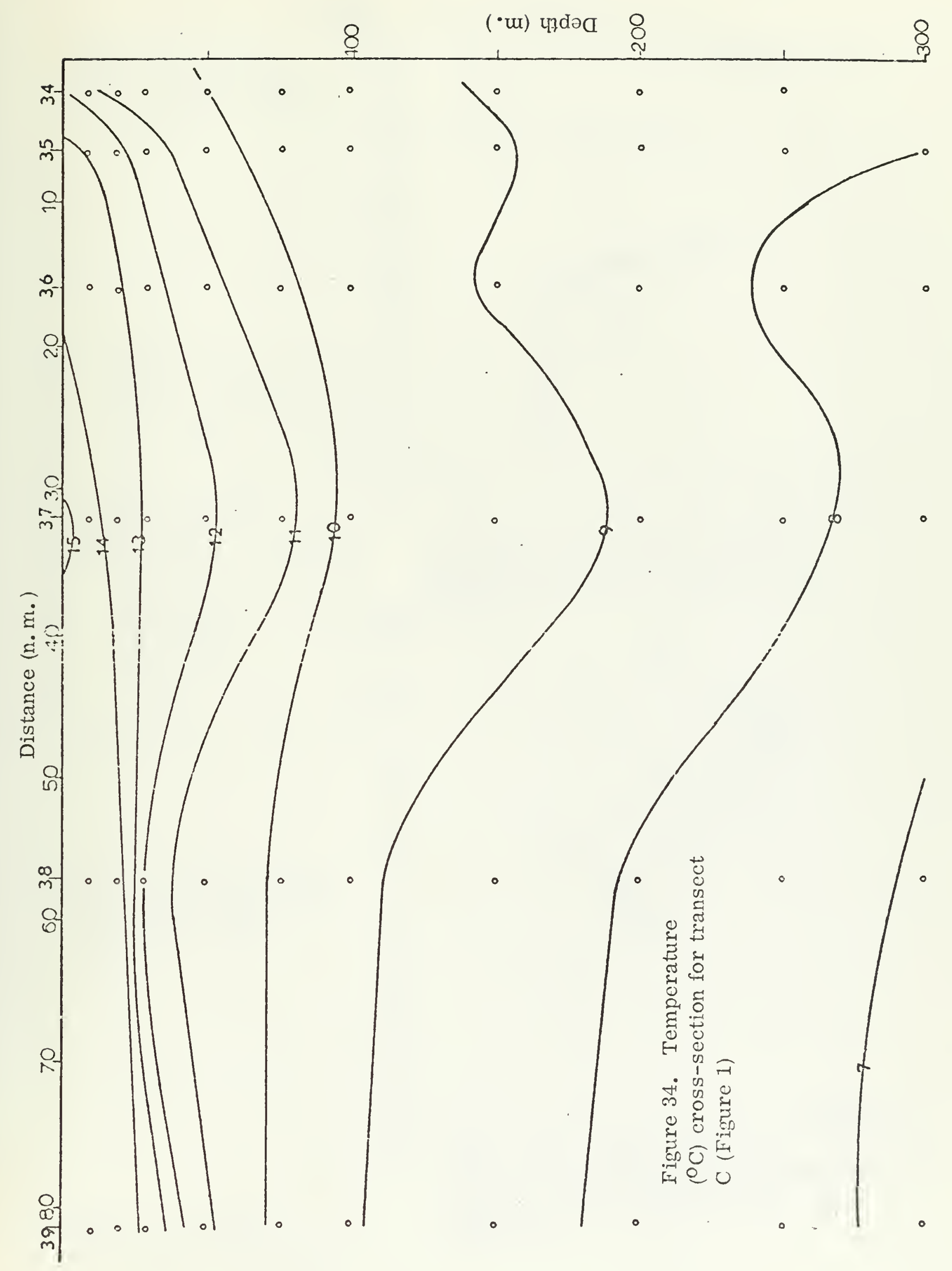



Temperature $\left({ }^{\circ} \mathrm{C}\right)$ at $20 \mathrm{~m}$. for Southern Shallows Statlons (NPS 1 and Hopkins 1).

Key to Symbols:

South

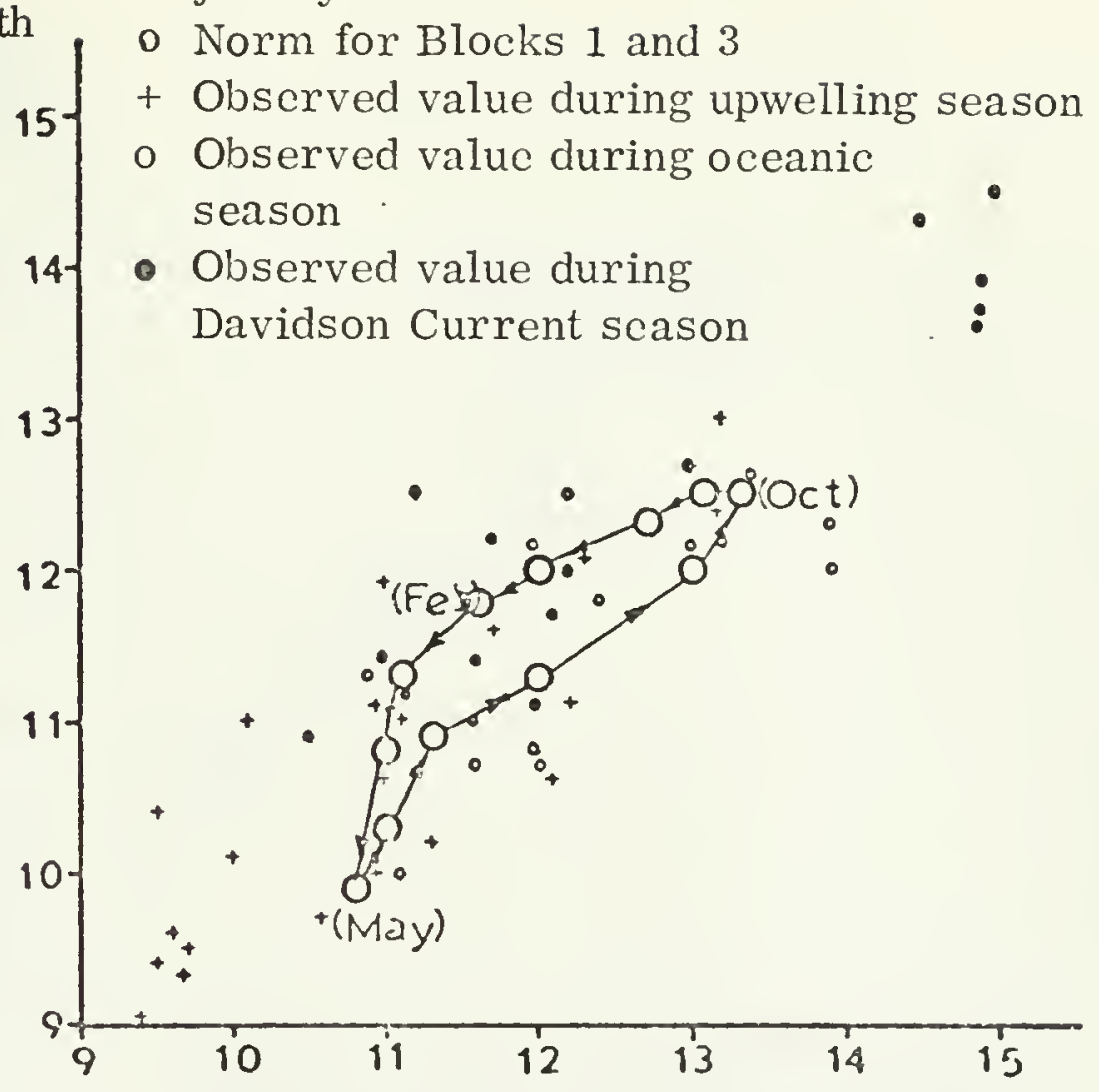

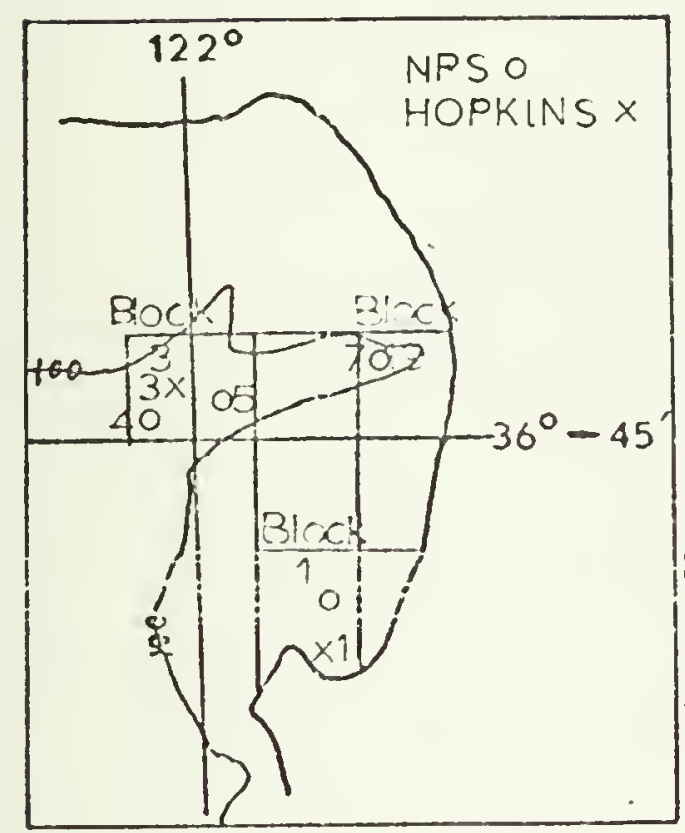

Sea Surface Tempcrature $\left({ }^{\mathrm{O}} \mathrm{C}\right)$ at Shouthern Shallows Stations (NPS 1 and Hopkins 1)
Figure 35. South to North Gradicnt Diagrams
Tempcrature $\left({ }^{\circ} \mathrm{C}\right)$ at $20 \mathrm{~m}$. for Deep Canyon Location Stations (NPS 5 and Hopkins 3).
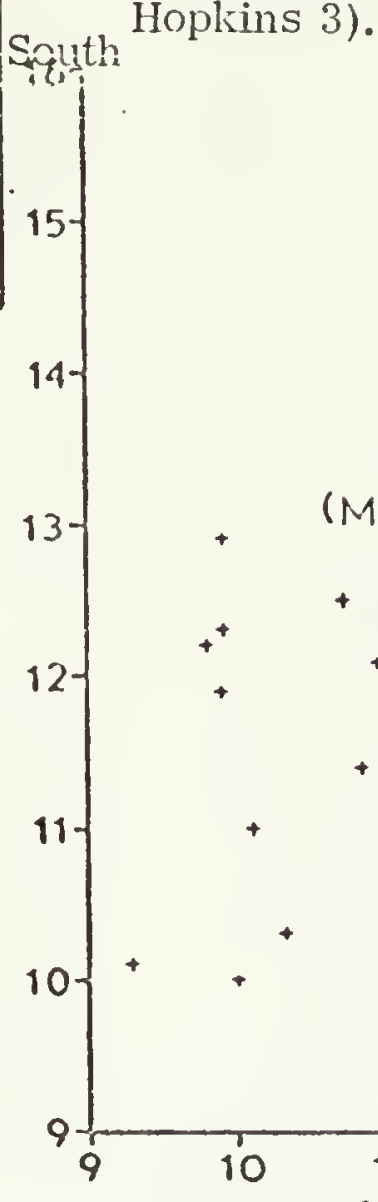

\section{$35 \mathrm{~B}$}

North

Sea Surface Temperature $\left({ }^{\circ} \mathrm{C}\right)$ at Deep Canyon Location Stations (NPS 5 and Hopkins 3). 



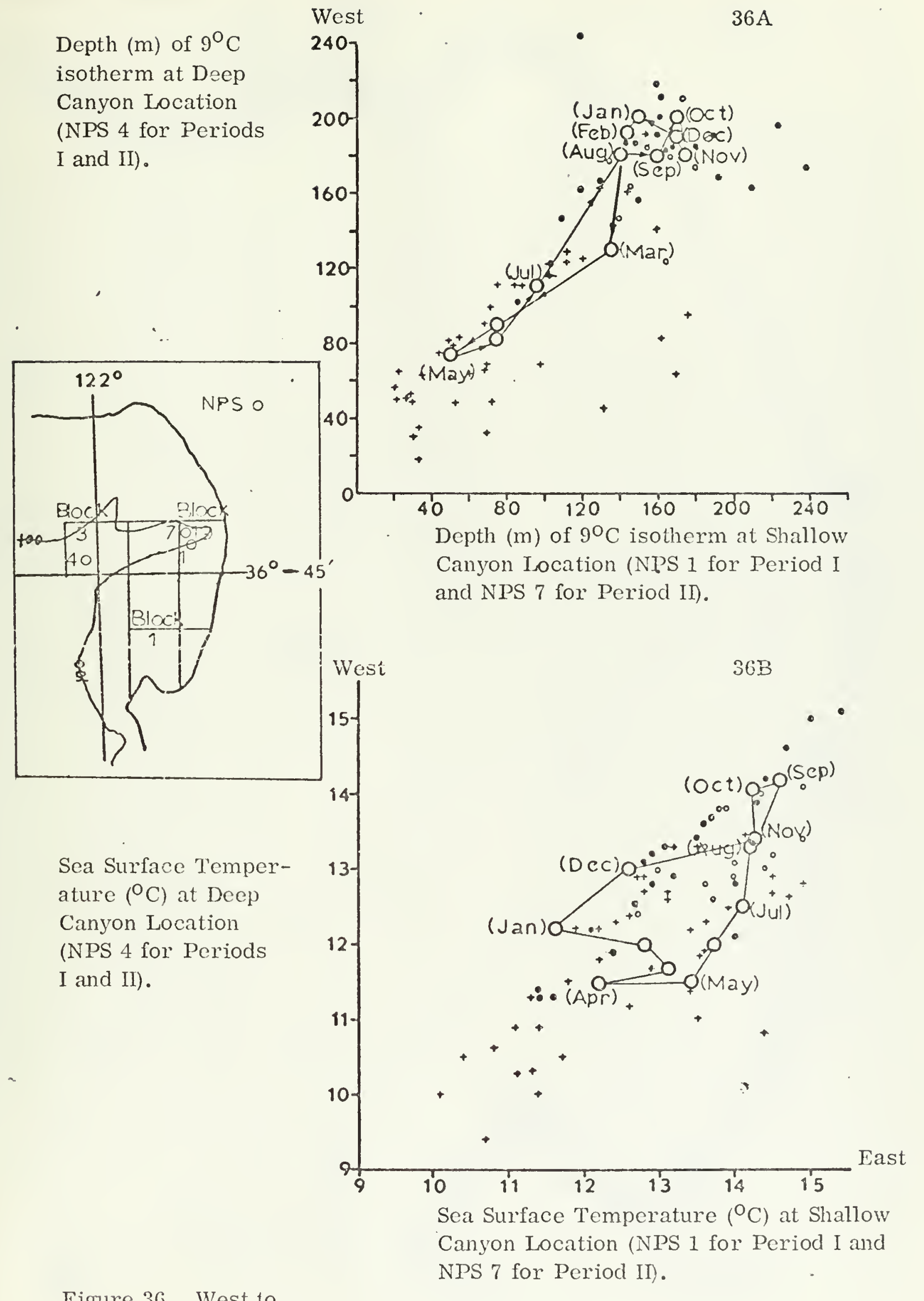

Figure 36. West to

East Gradient Diagrams

(See Figure 35 for key to 



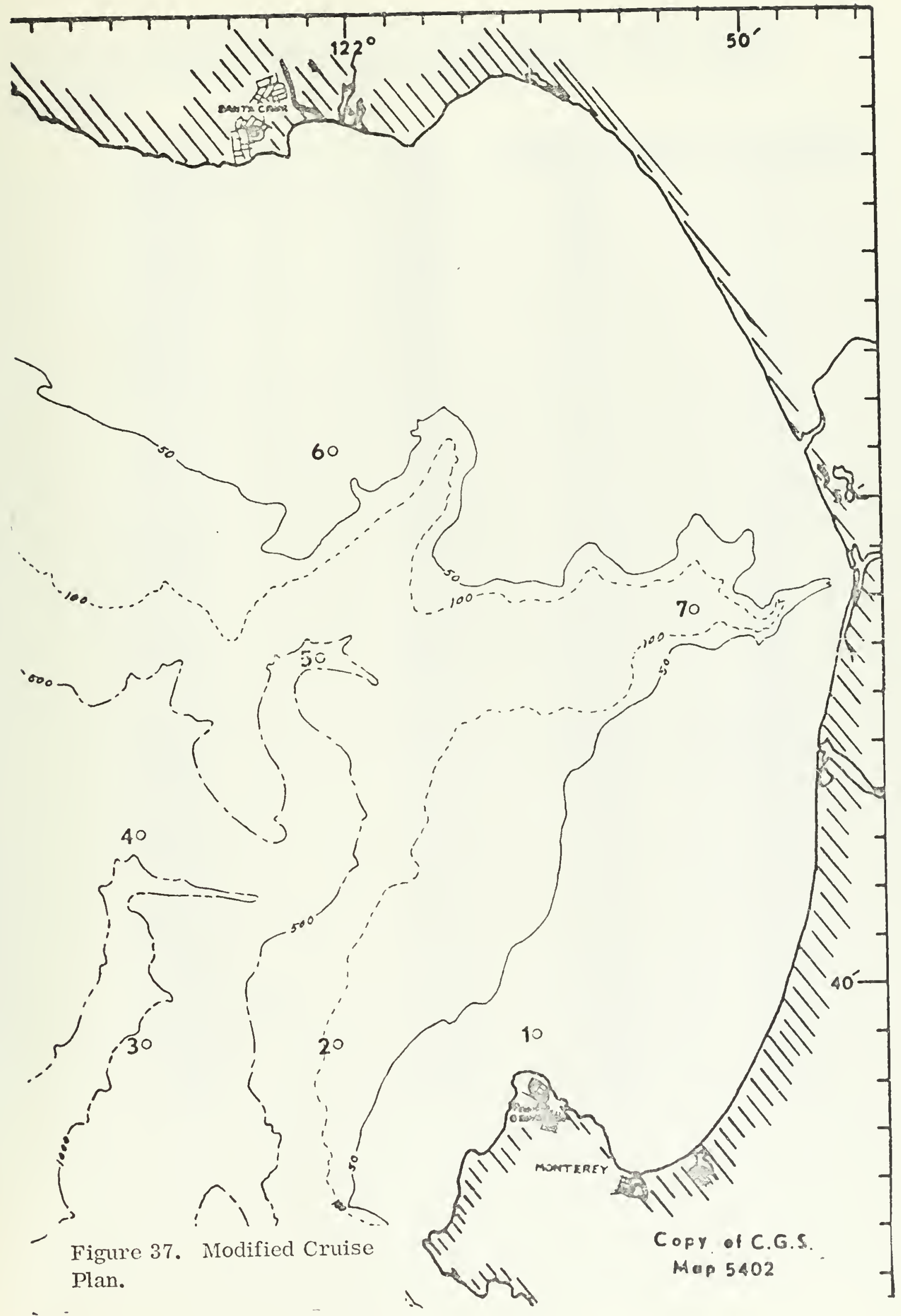



TABLE I: DEVIATIONS OF SST $\left({ }^{\circ} \mathrm{C}\right)$ FROM NORM AT DEEP CANYON LOCATION (NPS STATION 4 AND BLOCK 3 RESPECTIVELY) DURING PERIOD II

DATE
22 Jan 1970
$29 \mathrm{Jan}$
$7 \mathrm{Feb}$
$12 \mathrm{Feb}$
$27 \mathrm{Feb}$
$12 \mathrm{Mar}$
$19 \mathrm{Mar}$
$26 \mathrm{Miar}$
$4 \mathrm{Mar}$
$10 \mathrm{Apr}$
$15 \mathrm{Apr}$
$22 \mathrm{Apr}$
$14 \mathrm{May}$
$21 \mathrm{Nay}$
$25 \mathrm{May}$
$11 \mathrm{Jun}$
$18 \mathrm{Jun}$
$26 \mathrm{Jun}$
$1 \mathrm{Jul}$
$9 \mathrm{Jul}$
$17 \mathrm{Jul}$
$22 \mathrm{Jul}$
$16 \mathrm{Sep}$
$24 \mathrm{Sep}$
$29 \mathrm{Sep}$
$7 \mathrm{Oct}$
$21 \mathrm{Oct}$
$29 \mathrm{Oct}$
$3 \mathrm{Dec}$
$10 \mathrm{Dec}$
$17 \mathrm{Mar} \quad 1971$
$24 \mathrm{Mar}$
$2 \mathrm{Apr}$
$7 \mathrm{Apr}$

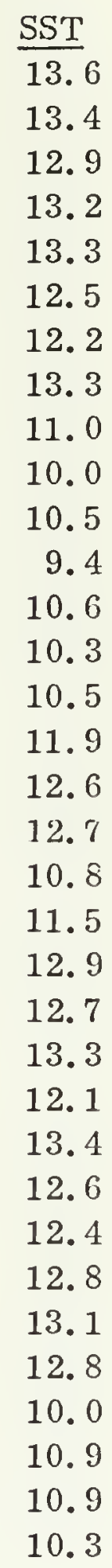

$\frac{\text { MONTHLY NORM }}{12.2} \frac{\text { DEVIATION }}{+1.6}$

12.2

$+0.8$

12.0

12.0

12.0

11.7

11.7

11.7

11.7

11.5

11.5

$+0.9$

$+1.2$

$+1.3$

$+0.8$

$+0.5$

$+1.6$

$-0.7$

$-0.5$

$-1.0$

11.5

$-2.1$

11.5

11.5

11.5

12. 0

12.0

12.0

12.5

12.5

12.5

12.5

14. 2

$-0.9$

$-1.2$

$-1.0$

$-0.1$

$+0.6$

$+0.7$

$-1.7$

$-1.0$

$+0.4$

$-0.2$

$-0.9$

14.2

$-2.1$

14.2

$-0.8$

14.1

$-1.5$

14.1

$-1.7$

14. 1

$-1.3$

13. 0

$+0.1$

13.0

$-0.2$

11.7

$-1.7$

11.7

$-0.8$

11.5

$-0.6$

11.5

$-1.2$ 

TABLE II: DEVIATION OF SST $\left({ }^{\circ} \mathrm{C}\right)$ FROM NORM AT A SHALLOW CANYON LOCATION (NPS STATION 7 AND BLOCK 19 RESPECTIVELY) DURING PERIOD II

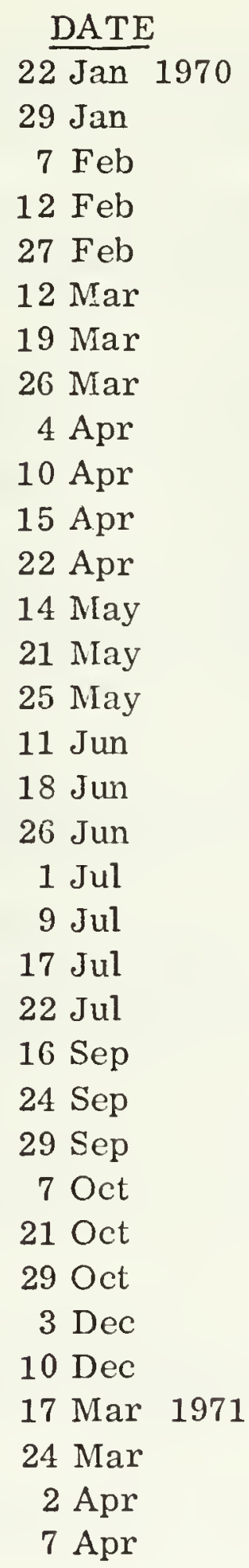

$\frac{\mathrm{SST}}{13.6}$

13.5

13.2

12.9

13.2

13.9

13.4

13.5

13.5

11.4

10. 4

10.7

10.8

11.3

11.7

13.6

13.1

14.5

14. 4

11.8

12.8

12.8

13.1

14.0

14.9

13.7

12.7

13.6

12.8

12.9

10.0

11.1

11.4

11.1

\section{MONTHLY NORM DEVIATION \\ 11.6 \\ $+2.0$}

11.6

12.8

12.8

12.8

13.1

13.1

13.1

12.2

12.2

12.2

12.2

13.4

13.4

13.4

13.7

13.7

13.7

14.1

14.1

14.1

14.1

14.6

14.6

14.6

14.2

14.2

14.2

12.6

12.6

13.1

13.1

12.2

12.2
$+1.9$

$+0.4$

$+0.1$

$+0.4$

$+0.8$

$+0.3$

$+0.4$

$+1.3$

$-0.8$

$-1.8$

$-1.5$

$-2.6$

$-2.1$

$-1.7$

$+0.5$

$-0.6$

$+0.8$

$+0.3$

$-2.3$

$-1.3$

$-1.3$

$-1.5$

$-0.6$

$+0.3$

$+0.5$

$+1.5$

$+0.6$

$+0.2$

$+0.3$

$-3.0$

$-2.0$

$-0.8$

$-1.1$ 



\section{BIBLIOGRAPHY}

1. Abbott, D.P. and Albee, Riehard, "Summary of Thermal Conditions and Phytolankton Volumes Measured in Monterey Bay, California 1961-1966," CalCOFI Report No. 11, p. 155-156, 1967.

2. Moss Landing Marine Laboratories' of the California State Colleges Publication 71-1, Monterey Bay Bibliography, ed. by Doris Baron, p. 1-259, March 1971.

3. Bigelow, H.B. and Leslie, Maurine, "Reeonnaissanee of the Waters and Plankton of Monterey Bay, "Bulletin of the Nuseum of Comparative Zoology at Harvard College, v。70, no. 5, p。430-573, May 1930.

4. Offiee of Naval Researeh Contraet N6 onr-25127, Hydrographie Data From the Area of the Monterey Submarine Canvon, 1951-1955, by R. L. Bolin and Collaborators, p. 1-101, 30 July 1964 .

5. Bolin, R。L. and Abbott, D。P., "Studies on the Marine Climate and Phytoplankton of the Central Coastal Area of California, 1954-1960, "CalCnFI Report No. 9, p. 23-45, 1963.

6. Hopkins Marine Station of Stanford University Unpublished Annual Reports, CalCOFI Hydrographie Data, Collected on Approximateiy Weekly Cruises on Norterey Bay, California, January-Deeember, Sponsored by the Marine Researeh Committee, 1966, 1967, 1970.

7. Jennings, F.D. and Sehwartzlose, R. A., "Measurements of the California Current in March 1958," Deep-Sea Research, v. 7, p.42-47, 1960.

8. Lammers, L. L. , A Study of Mean Monthly Thermal Conditions and Inferred Currents in Monterey Bay, Master's Thesis, Naval Postgraduate Sehool, Monterey, California, 1971.

9. Munk, W. H., "On the Wind-Driven Cireulation, "Journal of Meteorology, v. 7, no. 2, p. 79-93, April, 1950.

10. Reid, J. L., "Measurements of the California Countercurrent at a depth of 250 meters, "Journal of Marine Researeh, v. 20, p. 134-137, 1962. 

11. Reid, J. L., Roden, G. I. , and Wyllie, J. G., "Studies of California Current System," CalCOFI Progress Report 1 July 1956 to 1 January 1958, Marine Research Committee, California Department of Fish and Game, 1.27-56, 1958.

12. Reid, J. L. and Schwartzlose, R. A., "Direct Measurements of the Davidson Current off Central California, "Journal of Geophysical Research, v.67, no. 6, p. 2491-2497, June 1962。

13. Schwartzlose, R. A., "Nearshore Currents of the Western United States and Baja, California as Measured by Drift Bottles," CalCOFI Report no. 9, p. 15-22, 1963.

14. Skogsberg, To, "Hydrography of Monterey Bay, California. Thermal Conditions, 1929-1933," Transactions of the American Philosophical Society, vo 29, p. 1-149, December 1936.

15. Skogsberg, T., and Phelps, A., "Hydrography of Monterey Bay, California. Thermal Conditions, Part II (1934-1937), " Proceedings of the American Philosophical Society, v. 90, no. 5, p. 350-386, 1946.

16. Sverdrup, $H_{c}$ U., Johnson, M. W. : and Fleming, R. H., The Oceans: 'Iheir Physics, Cinemistry, and Generai Bioiugy, Pientice-Hail, 1942.

17. Wooster, W. S., and Reid, J. L., "Eastern Boundary Currents," in The Sea, Vol. 2, ed. by M. N. Hill, Interscience Publishers, New York, 253-280. 

No. Copies

1. Defense Documentation Center

Cameron Station

Alexandria, Virginia 22314

2. Library, Code 0212

Naval Postgraduate School

Monterey, California 93940

3. Department of Oceanography, Code 58

Naval Postgraduate School

Monterey, California 93940

4. Dr. Ned A. Ostenso

Office of Naval Research, Code 480D

Arlington, Virginia 22217

5. Oceanographer of the Navy

The Madison Building

732 N. Washington Street

Alexandria, Va 22314

6. Professor D. F. Leipper, Code 58Lr.

Department of Oceanography

Naval Postgraduate School

Monterey, California 93940

7. Professor S. P. Tucker, Code 58Tc

Department of Oceanography

Naval Postgraduate School

Monterey, California 93940

8. Professor J. J. von Schwind, Code 58Vs

Department of Oceanography

Naval Postgraduate School

Monterey, California 93940

9. President

Marine Technology Society, Code 58

Monterey Chapter

Naval Postgraduate School

Monterey, California 93940 

No. Copies

10. Chairman

Association of the Monterey Bay Area

1

Governments (AMBAG)

Monterey, California 93940

11. National Dceanographic Data Center (NODC)

Washington, D. C. 20202

12. Director

Hopkins Marine Station of Stanford University

Pacific Grove, California 93950

13. Director

Moss Landing Marinc Laboratories of the

California State Colleges

Moss Landing, California 95039

14. LCDR Raymond C. Anderson, USN

USS SAILFISH (SS572)

c/o F.P.O. San Francisco 96601 

Securify classilication of thle, body of abstractand indexing anno:alion must be antered when the overall report is classified) ORIGINATING ACTIVITY (CORPORATE author)

Naval Postgraduate School

Monterey, California 93940

\section{REPORT TITLE}

Thermal Conditions in Monterey Bay during September 1966 through

September 1967 and January 1970 through June 1971

1. OESCRIPTIVE NOTES (TYPo ol reporl and.inclusive daces)

Master's Thesis; September 1971

AUTHORISI (First name, middlo inillal, last namo)

Raymond C. Anderson

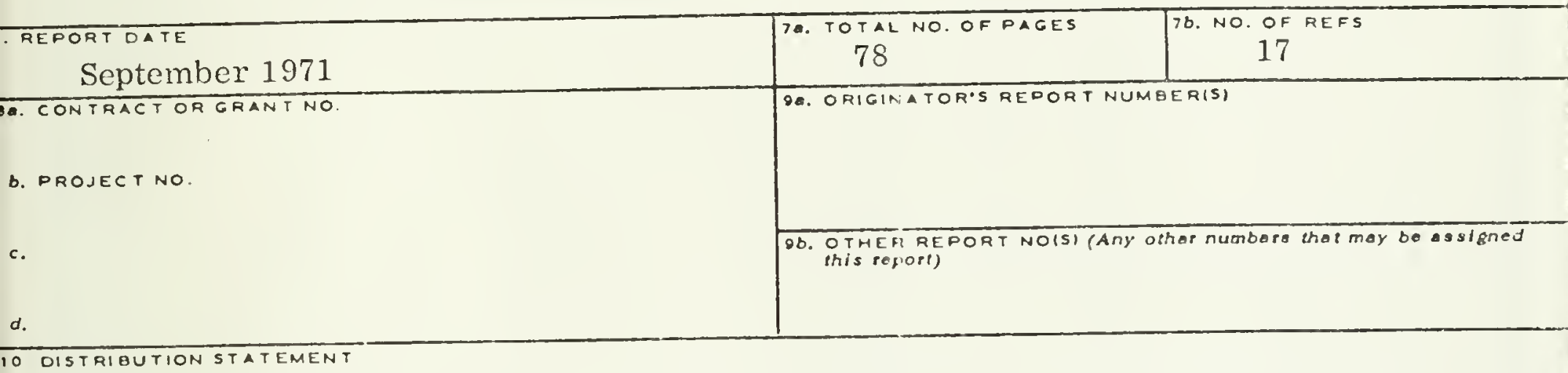

Approved for public release; distribution unlimited.

Thermal conditions in Monterey Bay during September 1966 through September 1967 and January 1970 through June 1971 were described by comparing direct observations taken at nearly weckly intervals to the long-term (40 years) averages, or "norms," developed by Lammers (1971). Station locations were distributed throughout the bay with most located over the axis of Montercy Submarine Canyon or in the southern half of the bay. Temperature data from three transects taken out to a distance of some 80 miles in August 1970 were compared to observed thermal conditions in the bay during four quasi-synoptic (one to three day)periods in August.

It was found that the norms provide an excellent basis to which direct temperature observations during quasi-synoptic periods may be compared. Such comparisons of certain thermal indices (depth of the $9^{\circ} \mathrm{C}$ isotherm, temperature at 20 meters, and sea surface temperature) at key locations (southern shallows, deep canyon, and shallow canyon) are valuable parameters in identifying the three climatic seasons (upwelling, oceanic, and Davidson Current) as well as the existence of anomalous thermal conditions. Further study into the nature of these anomalies could lead to better understanding of the dynamics of witer movements in Nonterey Bav. 

Monterey Bay

California Current

Davidson Current

Upwelling

Synoptic (quasi) Thermal Conditions 







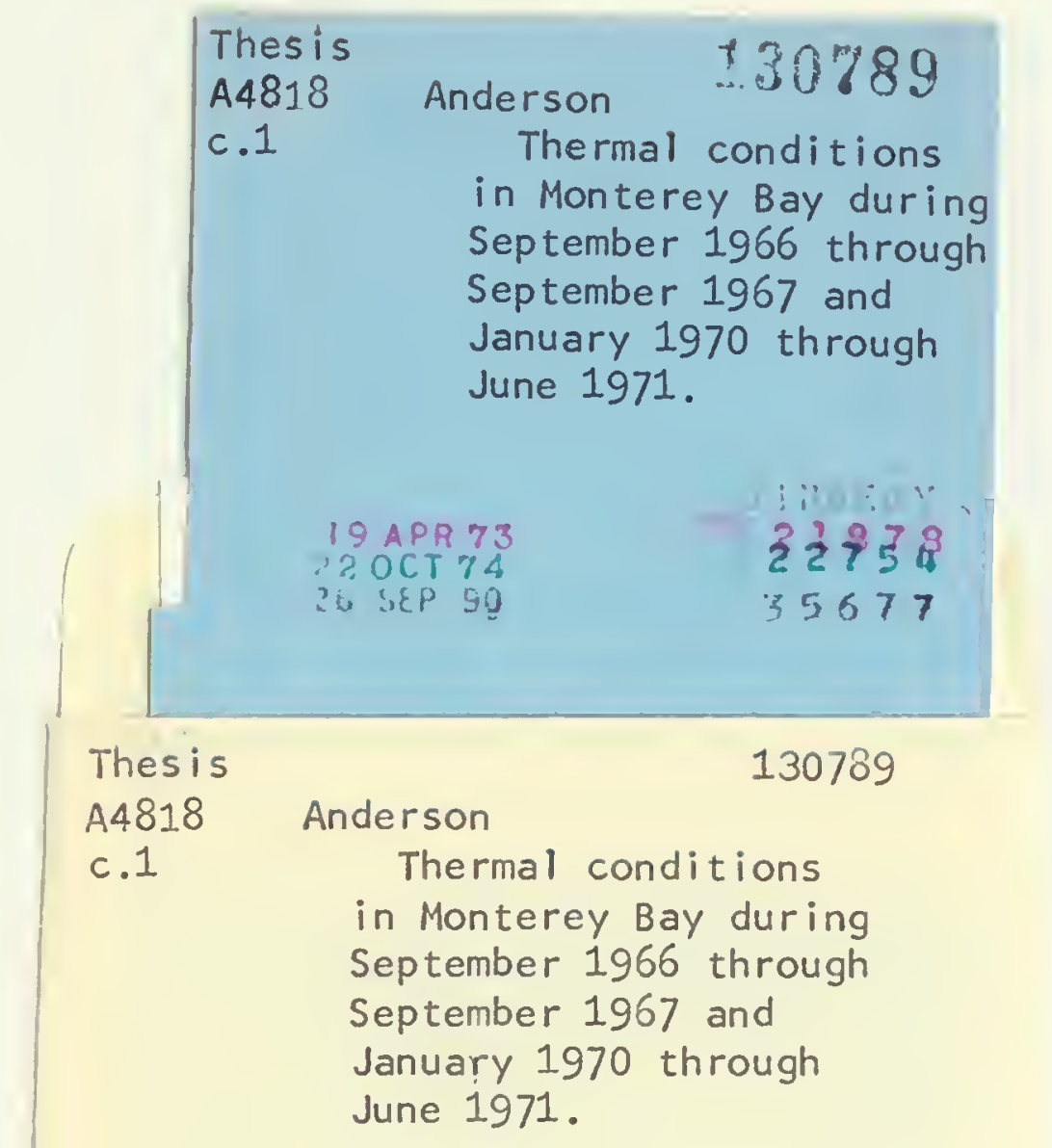


Thermal conditions in Monterey Bay durin (II)

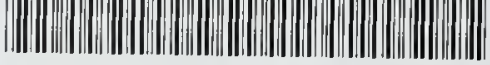
32768001914971 DUDLEY KNOX LIBRARY 